\title{
دورُ الدولة والمجتمع في مواجهة الفقرِ في الأندلس من عصر الاولة الأموية وحتى نهاية
}

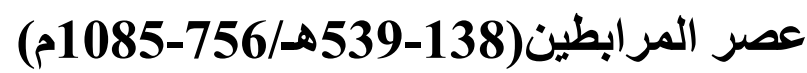

عبير عيد محمد

$$
\text { إثراف }
$$

أ.د/ عفيفى محمود إبراهيم *** أ.د/ أحمد إبراهيم الشعراوى ** - (

\section{المستخلص :}

هدفت الدراسـة إلى التعرف على دور الدولةِ والمجتمع في مواجهة الفقر ، وذلك من خلال إبراز أثر الفقر في سيادة ثقافة التكافل والتآزر لدى حكام وشرائح المجتمع المختلفة تجاه تلك الفئات المحرومة والمهمَّشَة في المجتمع وذلك من خلال التعرُف على الجهود المبذولة؛ لتحسـين أوضـاعهم من خلال تقديم الدعم المادي والمعنوي وقضاء حوائجهم من قِبل الحُكام ومؤسسات الدولة ومختلف شرائح المجمع، فقد سعين إلى عرض هُ الدور والجهد الذي قدمه الحكام للفئات الفقيرة والمحتاجة، كتقديم الصـــدقات الاختيارية والحرص علي توزيع الزكاة، وتقديم الرعاية الطبية، وإتاحة مجانية التعليم للفقراء، والاهتمام بتوفير المشاريع الخدمية التي تساعدهم كالاهتمام بتوفير المياة، والتخلص من الجرد هذا بجانب السـماح للفقراء بتقديم شـكواهم وتخفيف الضــرائب عنهم، ثم عرضـنا دور مؤسـســيّ القضـاء والحسبة ومحاولتهم في رفع مسـتوى المعيثــة للفئات الضـعيفة

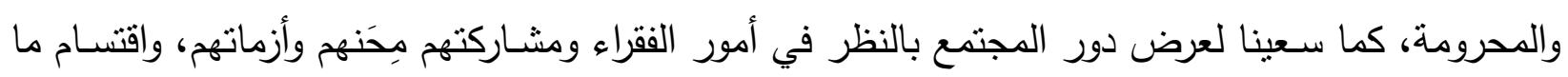
لديهم معهم كوقف أوقاف دائمة أو موقتة لهم، لذلك شكل كل من الحكام ومؤسـسـات الدولة والمجتمع نسـًا كاملًا لاعم الفقراء.

$$
\text { الكلمات المفتاحية : أندلس - الفقراء - الحكام - المجتمع - الرعاية- القضاء - الحسبة. }
$$


تحاول الدراسـة الإجابة عن عدَّة إثــكاليات أهمها: كيف سـاهم الحكام في تقديم الدعم للفقراء، وذلك من خلال الحكم على سياسات الدوّل المعاصرة لفترة الدراسة، أكانت تدعم الفقراء وتقلل من دائرة الفقر ؟! .. هذا فضلًا عن الحكم على المجتمع من حيث كونه مجتمعًا متضامنًا اجتماعيًّا مع الفقراء أم غير منضامنٍ؟ الاراسات السابقة: - n مليكة عدالة :ظاهرة الفقر بلاندلس في العصر الموحدي،مجلة عصور ،ع24-2015،25م أهميَّة الموضوع: تكمُن أهميَّة الموضوع في إبراز جانب من جوانب الحياة الإجتماعية في الأندلس ويظهر لنا بشكل أوضح مدى تعاون الدولة في الرفع من مســتوى الطبقات الفقيرة، بجانب إظهار تعاون طبقات المجتمع المختلفة في مواجهة الفقر والحد منه. منهج الدراسة: اعتمدت الدراسة علي المنهج الوصفي التاريخي.

المقدمة:

إن الأحداث السـياســية للدول المختلفة أصــبحت معروفة ومطروقة من قِبِلِ جُل الباحثين في تاريخ الأندلس، فضـــَّ عن تركيز معظم المصــادر التاريخية على تســيل تفاصــيل أحداثها، أما إذا نظرنا إلى النواحي الاجتماعية فسـندد أنه على الرغم من التقدم الذي أحرزته بعض الدراسـات فيها، فإن الدراسـات التي اهتمت بالتاريخ الاجتماعي في الأندلس ما زالت قليلة، وقد يُعزى ذلك إلى قلـة المادة التاريخيَّة من جهة، بجانب ســهولة تتاول مجريات التاريخ السـياسـي وتوافر مادته من جهةٍ أخرى، ويمثل موضــوع دور الدولة والمجتمع في مواجهة الفقر أحد موضــــوعات التاريخ الاجتماعي التي أُغفلت من قبل الباحثين في تاريخ الأندلس، على الرغم من أهمية الموضوع الذي يُلقي الضوء علي صور التضامن مع الفقراء من قبل السلطة الحاكمة، وغيرها من فئات المجتمع المختلفة . 
إســــهام الحكام والأمراء في تقديم الدعم للفقراء ماديَّا، وذللك من خلال توزيع الصــــــات الإختيارية والاهتمام بجمع الزكاة وتوزيعها على الفقراء فضــلًا عن الدور الخدمي من خلال تقديم العديد من المشـاريع الاجتماعية للفقراء متل مشــروع إطعام الفقراء أوقات المجاعات والجفاف، فضــلً عن الرعاية الطبية للفقراء ومجانيّة التعليم ورفع الضرائب والاستماع إلى شكاوي هذه الفئات الضعيفة وغيرها. هذا فضـلًا عن دور مؤسسـات الدولة المختلفة في دعم الفقراء، مثل مؤسستي القضـاء والحِسبة، فقد

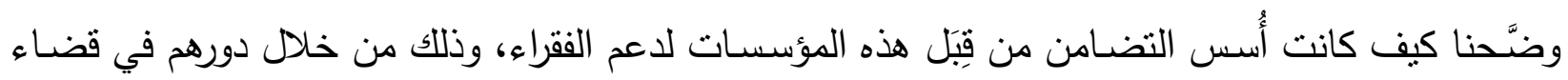
حوائجهم ودورهم زمن الكوارث والمِحَن، بجابب الدعم المادي لثــرائح الفقراء والمعوزين، وأخيرًا وضـــنا دور المجتمع في تقديم الدعم للفقراء وذلك من خلال صور التآزر والتكافل بين شرائح المجتمع المختلفة، وذلك من خلال الرعاية الطبية وقضاء الحوائج والدعم المادي والمعنوي أيام الأزمات ثم وضحنا أهمية الوقف ودوره في حياة الفقراء.

\section{أولاً: إسهام الحكام والأمراء في تقديم الدعم للفقراء ماديَّا وخدميًّا:} - الاعم المادي (الصدقات الاختيارية): نالت شــريحة الفقراء والمحتاجين اهتمامًا كبيرًا من قبل أمراء الدولة الأموية، فـــعوا إلى تحســين أوضـاعهم المادية وذللك من خلال توزيع الصـدقات الاختيارية عليهم، فما أثز عن الأمبر هثـام بن عبد الرحمن (172-180هــ- 788- 796م) المشهور بالعدل والسماحة والطيبة وأعمال البر والخير ، أنه كان يخرج من قصـره ليلًا، يجول شـوارع قرطبة ويذخل أكواخ الفقراء ويشـق عليهم ويهتم بآلامهم ويلبي حوائجهم (ابن الأثير،1987م، ج5 ، ص 308؛ المراكثــي ، 2006م، ص 24؛ الذهبي،1996م،ج8، ص 253؛ مجهول،1989م، ص 109؛ مجهول،2007م، ص170؛؛ كرد علي، 1923م، ص118؛؛ عنـان،1997م، ق1، ج1، ص 224 - 225؛ دوزي ،1995م، ج1، ص 57 - 98)، وقد وصفه المستشرق سيديو قالاً: 
" ولم يبالِ أمبر بسعادة شعبه المادية مبالاة هشام فكان يوزع الصدقات بسخاء، وكان يُعنى كل العناية بإنثاء معاهد كثثرة حيث يجد البائســون وسـائل للعمل وأقوانًا للعيش " (لويس ســيديو ، د - ت، ص 157؛ فوزي

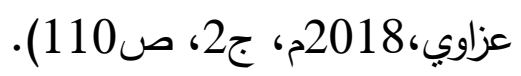
وكان من سُـنة بعض حكام الدولة الأموية فور توليهم الحكم أن يبسطوا للفقراء والمحتاجين ويغمروهم بعطفه وكرمهم كنوع من أنواع كسب صفوف العوام، كما فعل الأمير عبد الرحمن الأوسط (207- 238هـ822 -852 م) فعندما تمت له البيعة وتولى الحكم، أخرج خمســة آلاف دينارًا من صــلب ماله، فقرقها في أهل الحـاجـة والفـاقـة من أهل قرطبـة (مجهول، ج1983،1م، ص 138؛ مجهول، 2007م، ص 184185)، وهو مـا فعله الأمير المنذر بن محمد، فعندما نولى الحكم أخرج الأموال وفرق العطايا على الفقراء والمساكين وأسقط عنهم عُشر ذلك العام وما يلزمهم من خراج ومعونة (مجهول ، 1983م،ج1، ص 195)، ومن جهة أخرى خصص الأمير عبد الله بن محمد (275- 300هـ-888- 912م)، سهمًا من مال الجبايات لدعم الطبقات الفقيرة والمحتاجة (ابن حيان، 1994م، ج2، ص33 - 34 ؛ عنان، 1997م، ج1، ص 346 ؛ ضيف، 1989م، ص 64؛ فوزي عزاري، 2018م، ص 111)، وبوجه عام فقد عُرف عن الأمير عبد الله أنه كان جوادًا محبًا لأعمال الخير كثير البر بالفقراء وذوي الحاجات (ضيف 1989م ، ص 64). 
عمد بعض الحكام أيضًا إلى التقرب إلى الله عز وجل من خلال تقديم الصـدقات للفقراء والمحتاجين، وهو مسلك الخليفة الحكم المستصر ، الذي كثرت صدقاته في شهر رمضان، فيقول ابن حيان: " وفي غرة شهر رمضان من عام361هـ/ 971م جدد الخليفة الحكم المستتصر عادته التي لا يُخلّ بها في إفثـــــاء الصـــدقات ومظاهر القُربات ســـرّا وعلانية، فنعش الله بمعرفته أمة من ذوي الحاجة " (ابن حيان، 1994م، ص 23 ؛ عرفهه، ع11، يوليو 1993، ص130)، ولكن من أبرز الخدمات التي قدمها الخليفة الحكم تحبيســهـ ربع ما ورثه من أبيه في جميع كور الأندلس، فجعله وقفًا على الفقراء والمســاكين، ينتفعون بغلاته، وقد أثنه الفقهاء وأعيان الناس على ذلك (ابن عذاري، 1983م، ج2، ص 243 ؛ دويدار، 1994م، ص 260)، ولم يقف الأمر عند ذللك، الحد بل تعداه إلى بناء البيوت قبالة باب المســــد الكبير ، وجعلها للفقراء والمساكين وفقراء المسافرين وأصحاب الحاجات، وبني الخليفة الحكم دارًا للصدقة واتخدها مقرًا لتفريق الصدقات (ابن عذاري، 1983م، ج2، ص 240 ؛ لين بول، 2014م، ص 96).

ويبدو أن أمراء الدولة الأموية اتخذوا من احتفالاتهم الثخصية مناسبة لتفريق الأموال، والعطف على الفقراء، ونموذج ذلك ما فعله الخليفة الحكم المستتصر، عندما فرق الأموال على الفقراء والمحتاجين شكرًا له تعالى على جلوس ابنه هشــام لتلقي العلم بين يدي مؤدبه وقد اســتعان بالفقيه أحمد بن نصــر بتوزيع نلك الأموال (ابن حيان، 1965م،ص 77)، وبالمتل أخرج الصدقات للفقراء والمحتاجين تضرعًا لله تعالى، لشفاء ولي العهد هثـام من الجدري، فعندما كثـف الله عنه الضـر وأصبح معافى، اجتمع الخليفة الحكم في قصـره مع وزراءه ورجال دولته، وحمد الله على منته عليه بمعافاة ابنه هشــام وكلف الأمنين عبد الرحمن بن وافد وسـليمان بن أحمد الرصــافي بتوزيع الأموال على أهل السـتر والضــفاء (ابن حيان،1965م ، ج3، ص 154)، وهو ما أسـهم في تحسين أوضـاع كثثر من ضعفاء الناس (ابن حيان، 1965م، ج3، ص 153)، كذلك اعتمد الحاجب المنصور بن أبي عامر على أمية بن أحمد القرشي(ت393هـــ/1002م) في الإثراف 
على الصدقات وتفريقها في أوقات الأزمات (عياض، 1982م،ج7، ص 163)، كما عرف عن الخليفة هشام بن الحكم كثرة صدقاته على أهل الستر من الضعفاء والمساكين (ابن عذاري، 1993م،ج2، ص 253). ولدينـا من القرائن مـا يدل على حب عبد الملك بن أبي عـامر للخير والبر والعطف على الفقراء، ومبادرته لتوزيع الأموال على الفقراء والمســاكين (ابن الخطيب، ج2، ص 89 )، فقد أرســل مبلغًا من المال قدره خمسمائة دينار إلى أحد الصـالحين ويدعى أبو أيوب، وطلب منه أن يضعها في مكان ينتقع بها الفقراء والمسـاكين، فرأى الرجل الصـالح شـراء دار لإمام المسـجد، لأنه ليس له دار (ابن الخطيب، د-ت،ج2، ص

ولََم نجد إثـارات في فترة الفتنة القرطبية عن وجود صدقات للحُكام في هذه الفترة، حيث استمرت ثلاث وعشرون سـنة، وهو ما انعكس بالسـلب على المجتمع الأندلسي، فانشغل الحكام بتلك الإضطرابات فلم نجد منهم من يوزع الصـدقات أو يهتم لألم الفقراء وحاجتهم سـوى بعض الإثــارات البسـيطة، ومنها ما يبرز دور إدريس بن يحيى العلوي الحمودي، الذي كان كثير الدعم للفقراء حتي قيل عنه أنه كان عطوفًا على الطبقات الفقيرة والمعوزة كثير الصــقةة عليهم، (الحميدي، 1989م،ج1،ص 66؛ الضــب، 1989م، ص 61؛ ابن الأثير،1987م، ،ج8 ، ص 105؛ ســـيكو دي لوثثيا، 1992م،ص 42)، فكان يتصـــدق كل يوم جمعة بخمسمائة دينار على الضـفاء والمساكين، هذا بجانب الخدمات الجليلة التي قدمها من خلال رفع الظلم ورد المطرودين إلى أوطـانهم ورد ضــــاعهم وأملاكهم إليهم (ابن الآبـار،1985م، ، ج2، ص26؛ الحميدي ،

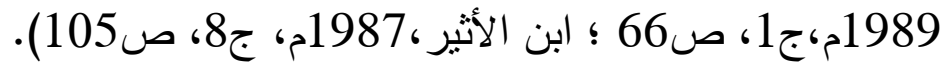

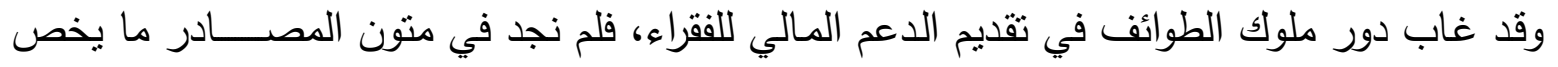
ملوك الطوائف من تقديم الصدقات الاختيارية للفقراء والمساكين، وذلك بسبب انشغالهم بالصراعات والحروب الداخلية فيما بينهم وحروبهم مع النصسارى من جهة أخرى، وقد أدى غياب دور السـلطة على ذلك النحو إلى تصدر القضاة والفقهاء والصلحاء في تقديم الصدقات والتخفيف من ألم الجوع والحرمان، هذا وقد اهتم بعض حكام المرابطين بتوزيع الصـدقات، ومنهم علي بن يوسـف بن تاثـفين، الذي عرف عنه حرصـه على إقامة 
العدل (الهرفي، 1985م، ص 69)؛ حتى اعتبره الكتاب من عدة الزهاد والمتبتلين (المراكثي، 2006م، ص 235 ؛ دندش، 1988م، ص 268)، فقد وصفه صاحب الحلل الموشية فقال:"... كان كثير الصدقة عظيم البر جزيل الصلة وألبسه الله المهابة وقذف الله له في القلوب المحبة فاجتمعت عليه الأمة " (مجهول،1979م، ص 83 - 84 ؛ الهرفي، 1985، ص 69).

\section{- الاهتمام بجمع الزكاة من الأغتياء وتوزيعها على الفقراء:}

من المعلوم أن الإمـام الحاكم هو الذي يتولى قبض الزكاة إمـا بنفســــهـ أو من ينوب عنه (اللخمي،

2011م، ج2، ص 917)، وقد علق ابن حجر على حديث ابن عباس المثــهور في الصــحيحين عن حث النبي - صلي الله عليه وسلم - عن أهمية الزكاة (1)، وقد ضرب لنا الأمير هثـام بن عبد الرحمن (172180هــ/ 788- 796م)، أفضل الأمتلة على أخذ الزكاة من الأغنياء ومنحها للفقراء، فقد كان".... حاكمًا بالســنة والكتاب قبض الزكوات من طرقها ووضــعها في حقها " ( ابن عذاري ،1983م، ج1، ص 244 ؛ بدر 2009م، ج2، ص 173؛ قرني، 2012م، ص 58 - 59 ؛ دوزي، 1995م، ج1، ص 79 - 80)، واستمر اهتمام الدولة الأموية بمسألة جمع الزكاة، وصرفها على الفقراء والمساكين خلال عصر الخلافة، فقد انتكى أهل طرطوشـة (2) إلى الخليفة الناصر ما كانوا يقاسونه من شدة هجمات العدو عليهم بسبب موقعهم؛ مما دفع الناصـر إلى ترك الزكاة والمغارم لهم تقوية لهم وتعويضًا عما يخربه العدو في بلادهم، وبالمنل كان

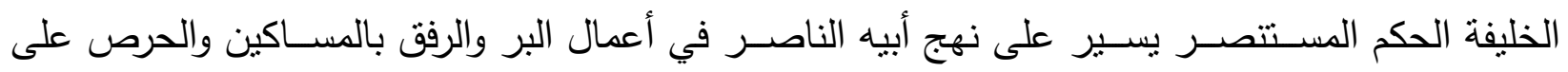
مصالحهم، فقد حث القاضي محمد بن إسحاق بن السليم (ت 367هـ/977م) على تشجيع الناس على إخراج الزكاة للفقراء وجمعها؛ فنادى القاضي بعد صـلاة الجمعة " إنه ليس بغائب عنكم ما فيه ضعفائكم ومساكينكم

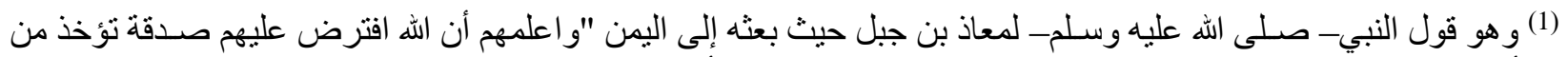

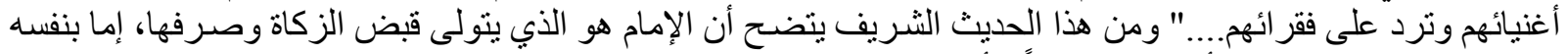

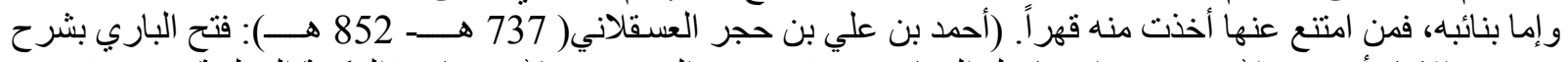

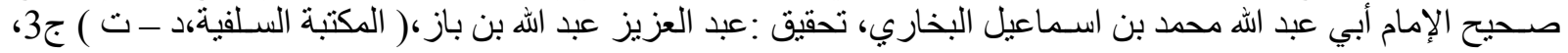

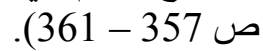
(2) طرطوشة: مدينة أندلسية تبعد عن بلنسة نحو مائة و عشرين ميلاً وهي بلد كبير تثتنهر بانتشار المر اكب و العمائر ويؤمها

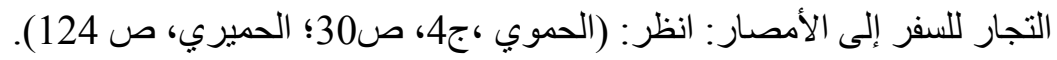


من الفاقـة والحـاجـة، فحصـــلوا زكاة أموالكم، وكفارة أيمانكم، ووصــــايـا أمواتكم، وعجلوا بها إلى فقرائكم ومحاويجكم، ولا تتاســوهم فهم غدًا خصــمائكم عند الله ربكم وهو شـــيد عليكم لا رب غيره" ( ابن حيان، 1979م، ص 68 ؛ حتاملة، 1999م، ج2، ص 658؛ ماهر حمادة، 1986م، ص 210).

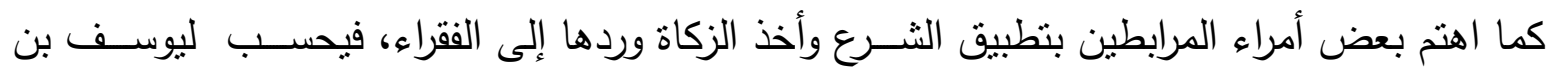
تاشـفين أنه أنقذ المسـلمين من براثن الضـرائب غير الثـرعية التي أفقرتهم، كما أمر بجمع الزكاة وتفريقها في وجوهها الصحيحة (ابن أبي زرع، 1972م، ص137 - 138؛ الهرفي، 1985م، ص 57 - 58)، وبالمثل كان الأمير علي بن يوسف (500- 537هــــ / 1106 -1143م) يسير على نهج أبيه في تحري العدل

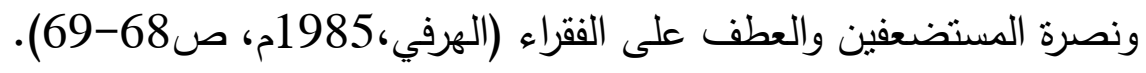
ويتضــح مما ســق أننا إذا قارنَّا موقف الدولة الأموية السـابق بخصـوص جمع الزكاة وتوزيعها على الفقراء مع موقف ملوك الطوائف المتخاذل من ناحية والمرابطين من ناحية أخرى، فسـوف نجد اختلافاً كبيراً يوضـــح لنا دور كل دولة منهم في مواجهة الفقر ودعم الفقراء، فنجد أنه لا يوجد إثـــارات تدل على اهتمام

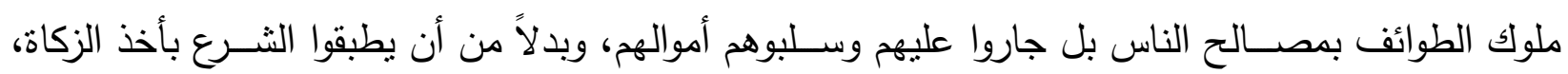
فرضوا عليهم ضـروبًا شتى من المغارم والضرائب؛ لتعويض العجز المالي الناتج عن سفههم في سياساتهم المالية، ومظاهر الترف والبذخ التي كانوا يعيثـــون فيها ودليل ذلك ما كان يجبيه مبارك ومظفر العامرين للإنفاق على ملذاتهم، إذ بلغت جبايتهم120ألف دينارًا من بلنسـة وشـاطبة، كانت تجمع بأنشـ طرق التعسف

$$
\text { والعنف (ابن عذاري، 1983م، ج3، ص 160). }
$$

وأيضًا نجد أبا الوليد بن جهور (ت462هـــ/1069م)، يعتدي على المسلمين ويستبيح أموالهم ويسلط

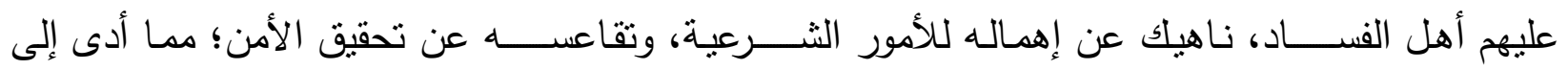
انتشـارالفوضى (ابن عذاري، 1983م،ج3، ص 233)، ولم يختلف ابن عباد كثيرًا فقد كان مشـغولًا بحروبه والتمثيل بجثث أعدائه، ولم يكن يبالي بأمور الفقراء (ابن عذاري،1983م، ج3، ص 206 - 208). 
وإذا تتبعنا غير هؤلاء من ملوك الطوائف نجد عجب العجاب فهذا الأمبر أبو بكر إبراهيم كان كثير الإنفاق والتبذل في المال ولكن ليس على الفقراء، فلم تذكر المصـادر عطفه عليهم ولا قبامه بالصدقات (ابن سعيد، 2004م، ص257 ؛ عويس، 1994م، ص20-25)، ومتلكه الأمير ابن تيفلويت صـاحب سـرقسطة وأبي بكر بن باجة، الذين انشـلوا بحضور مجلس الغناء والثـعر(ابن سعيد، 2004م، ص 257 - 258 ؛ المقري ، 1940م، ج2، ص 209 - 210)، وهكذا كان حال ملوك الطوائف، فقد وصف لنا أحد المؤرخين واقع المجتمع آنذاك بقوله: "... مشـتنظون بشـرب الخمر واقتناء القبان وسـماع العيدان ...، فصـعب على الطالب والمطلوب ذل الرئيس والمرؤوس وافتقرت الرعية، وفســـت أحوال الجميع بالكلية وزالت من النفوس الأنفة الإســـلاميـة " (ابن الكردبوس، 1996م، ج2، ص 1230 -1231)، فنجد إذن أن ملوك الطوائف أهملوا الأمور الثـرعية بما فيها الزكاة، وفرضـوا الضـرائب وانغمسوا في الملذات حتى أنهم فرضـوا الضـرائب

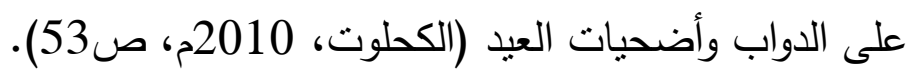
خلاصـة القول، أن ملوك الطوائف وبعض أمراء المرابطين انصرفوا عن أمور الحكم وتملصـوا من أداء واجباتهم الثـرعية ونزعوا إلى الترف والرفاهية لإرضـاء نزواتهم وشـهواتهم، فأصـبـح اهتمامهم بالبحث عن جواري الغناء أكثر من اهتمامهم بأمور الرعية ومحاولة إصلاح أوضاعهم. ثانيًا:الاور الخدمي: - إطعام الفقراء أيام المجاعات: - (إ) بقدر ما كانت المحن والثدائد السمة الغالبة في الدولة الأموية، وبقدر ما تعاظمت الثدائد على الناس، بقدر ما كان للحكام والأمراء دور فعال في مسـاندة الفقراء خلال نلك الأزمات، نموذج ذلك مما قام به الأمير هثام بن عبد الرحمن خلال المجاعة الثديدة التي حدثت عام 197هـ/812ه، وعانى الناس فيها من البؤس 
والجوع والحرمان وهو ما دفعه إلى إغاثة المعوزين والفقراء (مؤلف مجهول، 2007م، ص 169 - 174) حتى نال إعجاب الثعراء فقال عباس الجزائري (ت230هـ/844م) (34): نكد الزمان فأمنت أيامه من أن يكون بعصره عسير طلع الزمان بأزمة فجلاله لتلك الكريهـة جودة العمر وبالمثل برز دور الأمبر عبد الرحمن الأوسط في المجاعة التي اجتاحت الأندلس عام207هـ/ 822م، حيث غلت الأسعار فكاد الناس أن يهلكوا جوعًا ولكن الأمير عبد الرحمن قام بعمل موائد لإطعام الفقراء والمساكين من أهل قرطبة (ابن حيان، 2003م، ج2 ، ص 412 ؛ مجهول، 1983م، ص 139). وفي السياق ذاتة واجه الأمير محمد بن عبد الرحمن تداعيات مجاعة عام 260هـ/ 873 م، حيث قام الأمير بتخفيف حدة الأزمة وإســقاط جزء من العشــور بجانب مســاعدته للفقراء في إقامة عمارتهم في تلك الأزمات المجحفة، وهو ما نال إعجاب الرعية فدحه عثمان بن مثنى (ت 272هـ/885م) (4)، فقال: غدًا في أسارير الإمام محمد إمام الهاى بدور وفي كفه سحر تـلافى رعايـاه بإسقــاط وضرب الخليفة الناصر وابنه الحكم المستتصر أروع الأمتلة في تقديم الدعم للفقراء وإطعامهم، فقد أثر عنهم أنهم كانوا يطهون الطعام خارج القصر كل يوم ويقدمونه للفقراء والمسـين (ابن عذاري، 1983م، ج2، ص

ومما يؤكد حرص الخليفة الناصــر على مســاعدة ودعم الفقراء لاســيما أوقات الأزمات، اتخاذه مائة وعثــرون دارًا لتخزين الســـن والزيت والمؤن لوقت الحاجة (ســالم، 1997م،ج1، ص 239)، وقد جعل الناصــر جزء من أموال الجبايات مدخرًا لمواجهة مثل تللك الأزمات (ابن عذاري، 1983م، ج2، ص 231؛

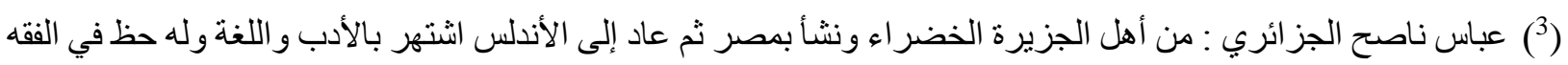

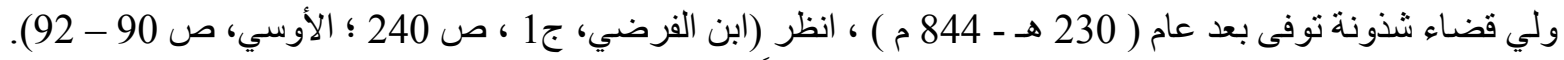

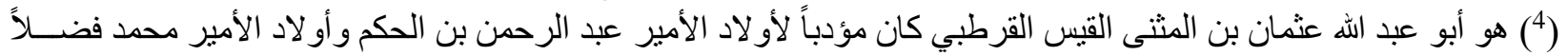

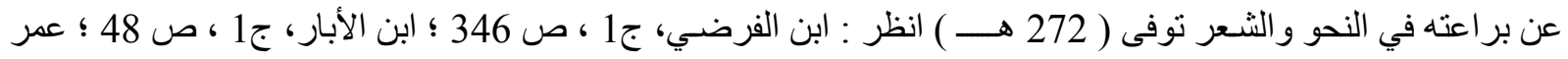


ابن الخطيب، د-ت، ص 38 ؛ المقري، 1940م، ج2، ص 271)، وبالفعل عندما اضــحلت البلاد ســنة 302هــ/ 914م، وغلت الأسعار وقل ظهور الحنطة في الأسواق وصلت المجاعة بالأندلس وبلغت الحاجة والعوز بالناس مبلغًا عظيمًا، لاسـيَّما وقد نزامن مع ذللك وقوع الوباء وكثر الموتى، فقام الناصـر بفتح مخازن الدولة ووزع المؤن على المســاكين وأهل الفاقة والمتعفقين من الناس، وبالمثل فعندما اســتـــرت المجاعة عام324هـــ - 935م، قام الناصر بعمل موائد لإطعام الفقراء والمعوزين وتزويدهم بما ينقصهم عن الطعام فاستطاع بذللك تجاوزالأزمة والتخفيف من معاناة الفقراء(ابن عذاري 1983م، ج2،ص 167- 168 ؛ عنان، 1997م، ص 424 ؛ الأخضـر ، ع16، 2018 م ، ص 91)، فمدحه الثــعراء، فقال عبد الله بن يحيى بن إدريس: نعم الثـفيع إلى الرحمن في المطر مسـتنزل الغيث والنذر (ابن حيان، 1979م، ج5، ص150 ؛

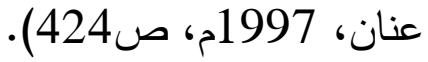

وفي إطار السـياسـية العامة فيما يخص الرفق بالرعية وتفقد شـئونهم قام الحكم المستتصـر علي أثز مجاعة عام (353هـ - 964ه)، بإطعام المسـاكين والفقراء في كل ربض من أرباض قرطبة، فكان يوزع اثتتي عشـر ألف خبزة بوميًّا على ضـعفاء قرطبة (ابن عذاري، 1983م، ج1، ص 236 ؛ عنان، 1997م، ج1، ص 478)، وكان من الســياســات الحســنة التي أثرت عن الحاجب المنصـــور ابن أبي عامر (ت ات 392هــ/1002م ) أن اتخذ التدابير اللازمة لمساندة الفقراء والمساكين أيام الأزمات، فقام بتخزين الأطعمة والمؤن حتى كان لديه في عام 374هـ / 984م، مخزون هائل من الأطعمة والمؤن يزيد علي مائتي ألف

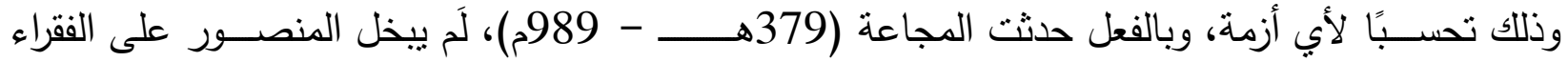
والمحتاجين بل قام بفتح مخازن الدولة وأطعم الفقراء والمحتاجين وظلت الحال هكذا ثلاث سنوات، يأمر بعمل اثثين وعشرين ألف خبزة يوميًّا تفرق على الضعفاء والمساكين، حتى انقضت سنوات المجاعة، فكان له من المآثر من خلال الرفق بالمســلمين وإطعام الضـــفاء، وتكفين الموتى، وإغاثة الأحياء ما لم يكن لملك قبله

$$
\text { (مجهول،1983م، ج1 ، ص صن 181 - 182). }
$$


يتضـــح مما ســـق أن الدولة الأموية، كان لها دور فعال في إطعام الفقراء والمســاكين لاســيَّما أيام المجاعات والأزمات عبر تدابير مسبقة، إلا أن الإثـارات المصدرية لَم تُسعفنا في هذا الصـد فيما يخص فتزة الفتنة القرطبية وعصر ملوك الطوائف، حيث سادت الفوضى وعمّت الاضطرابات وسادت كثير من القيم السـلبية في المجتمع فتقاعسـت السـلطة وتقاعس الأغنياء عن الدور المنوط بهم في دعم الفقراء والمحتاجين لاسيما أوقات الأزمات.

- الرعاية الطبية للفقراء: وقد اهتم حكام الدولة الأموية بكافة العلوم، ومنهم علم الطب، فثجعوا على الرحلة من أجل التعلم، واقتتوا أهم الكتب من جميع البلاد الخاصــة بعلم الطب، حتى وجد عدد كبير من أكفأ الأطباء في ذلك الوقت، وكل ذلك يصـب في مصـلحة رعاياهم (ابن جلجل،1985م،صص112 ؛ حسن قرني،2012م، ص98)، وإذا كان الفقراء أكثر تضـررًا من الإضـطرابات والتقلبات السـياسـية والعسـكرية، ناهيك عن الكوارث الطبيعية كالجراد والجفاف والمجاعات والأوبئة، فإنهم على الجملة كانوا أكثر عرضــة للأمراض المختلفة؛ لذا اهتم حكام الدولة الأموية برعايتهم، في ظل عدم قدرتهم علي دفع ثمن الأدوية أو أجرة الأطباء، نموذج ذلك إنثاء ربض خاص للاستشفاء في قرطبة علي يد الأمير هثام بن عبد الرحمن، فضلَاعن تطوعه بالصدقة علي مرضى الفقراء، وزيارة البعض منهم وحمل الأدوية بنفسـة إليهم، وهو ما كان يفعله مع أحد الزهاد (المراكثـي2006م، ج2،

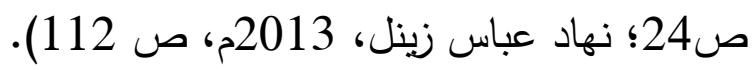
ففي عهد الأمير عبد الرحمن الثاني وخليفته محمد الأول، تمكن الطبيبان حمدين بن أبان، والمسيحي جواد إذخال العديد من المعاجين إلى فن الثفاء، وبعض المستحضرات من العسل وغيرها، ولم يذخر بعض الأطباء وسعًا في البحث عن علاج الفقراء والمساكين بالأدوية في تركيبات اقتصادية ملائمة لقدرتهم المادية، حيث تتوافر المعلومات عن تركيب ضــماد عامي مختصـر وكحل جيد للفقراء وغيرها من أصـناف الأدوية والعلاجات التي تليق بحال ووضـع الفقير، ناهيك عن الاهتمام بالطب الحرفي المتخصص في علاج العلل 
الناتجة عن ممارسة بعض أصناف المهن (الطاهري، 1995م، ص492) فكان اهتمام الأمراء بإنتاج الأدوية من أجل رعاياهم (ابن جلجل،1985م، ص 93 93). وكان للخليفة عبد الرحمن الناصــر وابنه الحكم المسـتتصــر دور كبير في رعاية المرضــى الفقراء والمحتاجين، فقد ســح الخليفة الحكم لطبيبه الخاص أحمد بن يونس بتوزيع الأدوية والعلاج لمن يحتاج إليه من الفقراء بالمجان من خزانته الخاصـة، فقد كانت لديه خزانة للطب لا يوجد منلها قط، رتب فيها اثنى عشر طبييًا فسـمح بتسـخير كل ذلك لخدمة الفقراء والمحتاجين(ابن جلجل، 1985م،ص 112؛ حسـ 2012م، ، ص 98)، وبالتأكيد اهتم حكام الدولة الأموية بإنشاء أرباض لمعالجة أصحاب الأمراض المعدية، خاصـة أن حكام الدولة الأمويـة كانوا يعملون على إحياء مجد دولتهم وحضــــارتهم في هذه المنطقة، وهو مـا جعلهم يثجعون الأطباء على ابتكار الأدوية وكانوا يغدقون الأموال الكثيرة في الأحياء الخاصـة بأصـاب الأمراض المستعصية (ابن بسام، 1997م، ق1، م2، ص 602 - 602 - 604). وقد اهتم المرابطون (484- 540هـ / 1144-1091م)، برعاية المرضى طبيَّا، فاعتبروا علم الطب مهنة مهمة، وعملوا على تطويرها، ووضعوا شروطًا لممارسة المهنة حتى يحافظوا على المجتمع الأندلسي من الجهلة ومدعي العلم، فقد أحدثوا منصــب رئيس الصــناعة الطبية لمراقبة أعمال الأطباء، وكان من ضــمن شـروطهم (الموسـاوي، ع3، 2013، ص 766)، عدم أخذ الدم من شـخص إلا بإذنه، وذلك للدحافظة على

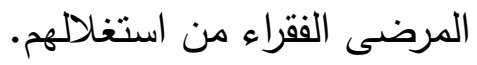

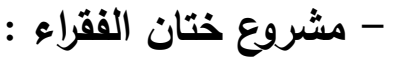

جرت العادة عند بعض حكام الدولة الأموية أنه عند قيام أحدهم بختان أبنائه يقوم بختان عدد من أبناء الفقراء مجانًا، وقد برز دور المنصور بن أبي عامر في هذا الصدد، فعندما قام بختان أولاده، قام بختان عدد لا يحصسى من أولاد الفقراء والمسـاكين، فبلغت النفقة عليهم في تلك الســة خمســائة دينار، " وهذه مكرمة مخلد ومنـة مقلدة " ( المقري، 1985م، ج2، ص 128 ؛ خلاف، 1984م، ص 306)، لَم تلكُ تلكك عادة 
جميع الحكام عند ختان أبنائهم علي مدار الفترة المدروســـة، فنجد مثلًا أن بعض ملوك الطوائف قام بعمل الحفلات لختان أبنائه، ولم يتذكر حتى إطعام الفقراء في مثل ذلك اليوم، فالأمير المأمون بن ذي النون أقام احتفالًا بختان حفيده يحيى، وظل الاحتفال قائمًا لعدة أيام، دعى فيها صـفوة المجتمع، وقد أعد للأمر عدته، فيذكر أنه أمر " بالاستكثار من الطهارة والإنقاء للقدور ، والإتراع للجفان، والصلة لأيام الطعام، والمشاكلة بين مقادير الأخباز والأدام، والأغراب في صــعة ألوانها مع شـباب أباريقها بالطيور الزكية....." (الزناتي، العدد

\section{الثامن عشر، ديسمبر 2012، ص 61 61، 67). - الاهتمام بتوفير الماء: -}

نظرًا لأهمية المياه وما تمتكه بالنســبة للإنســان وخاصــة في فترات القحط والجدب عمل بعض الحكام على توفير المياه العذبة، فقد شيد عبد الرحمن الأوسط قصبة ماردة وشبد بداخل تلك القصبة صـهريج تخزن فيه المياه الواردة من وادي نهر أنه (مورنيو، د.ت ، ص 51)، وجلب عبد الرحمن الثاني المياه العذبة إلى قرطبة بعد أن جزز موضـعًا كبيرًا لحفظ تلك المياه (ابن الأثير،1987م، ج1، ص 118)، وبنى بفضل هذه المياه الســقايـة التي على بـاب القصـــر للســـيل( ابن حيان،2003م، ج2، ص 280 - 281؛ ابن عذاري،1983م، ج2، ص 91)، وعندما أنشأ الخليفة الناصر مدينة المرية أحاطها بسور حصين، وأقام على ربضــها ســورًا من تراب وأمر عاملها خيران العامري بتوصـيل الماء إلى ربضـــها فقعل ثم وصــله محمد بن صـمادح إلى سـاقية عند جامعها داخل المدينة (الحميري، 1988م، ص 183 - 184؛ أبو الفذاء، د .ت ، ص 177)، وقد احتفل الخليفة الناصـر بشـق القناة العجيبة التي تصـب في بركة قصـر الناعورة في قرطبة (زيادة، 2010م، ص 144). وقد جلب الخليفة الحكم المسـتتصـر المياه من سـفح جبل بقرطبة إلى المســد الجامع بعد أن هدم الميضأة القديمة، وبنى موضعها أربع ميضـات في كل جانب من جانبي المسجد الثرقى والغربي، أجري في جميعها الماء من قناة شـــها من ســح جبل قرطبة، وأجرى الماء العذب إلى ســقايات اتخذها على أبواب المسجد بجهاته الثلاث الثرقية والغربية والثمالية (المقري ، 1988م،ج1، ص 555). 
وقد اهتم أمراء الأندلس ببناء الحمامات الخاصة بهم، فضلًا عن الحمامات العامة لجميع الناس، وذلك بسـبب أهميتها القصـوى للمســمين، فكان اهتمام الأمراء بها كبيرًا، فكان هذا سـر بناء الحمامات بالقرب من المسـاجد، وقد تسـابق الأمراء على بنائها حتى كثر عددها، لدرجة أن عددها كان يقرب عدد المسـاجد، فكان في قرطبة تسعمائة حمام، وقيل سبعمائة، أما حمامات النساء فقد وصلت إلى ثلاثمائة حمام (ابن الخطيب، د-ت، ص 41 ؛ ابن عذاري، 1983م، ج2، ص 233 - 234). - مجانية التعليم للفقراء:

الدارس لواقع الأندلس يجد أن الدولة الأمويـة كانت تريد إعادة بناء أمجادها في الأندلس، فاهتموا بالعملية التعليمية على أكمل وجه، ومن ذلك اهتمامهم بتعليم أولاد الفقراء والمحتاجين فقد حظي أولاد الفقراء بالتعليم، ويتضـح ذلك من بعض الإثـارات المصدرية حيث يقول الثقندي في رسـالته حين تعرض لمحاسن أنتبيلية: " وأما علماؤها في كل صنف رفيع أو وضيع، جدًا أو هزلًا، فأكثر من أن يعدوا، أثنـر أن يذكروا، وأما ما فيها من الثـعراء والوشـاحين والزجالين ما لو قسـموا على بر العدوة، ضـاق بهم، والكل ينالون خير رؤسائها ورفدهم ( ابن حزم، 1968، ج1، ص 52)، وقد اهتم حكام الدولة الأموية بتعليم أولاد الفقراء بشكل مباشر وآخر غير مباشر، بحيث أنشأ الحكام المساجد التي اعتبرت أهم المؤسسات التعليمية هي، ولم يكتفوا بإنشاء المساجد فقط بل كانوا يعينون لها القومة والخدم، وبلغ عددهم في المسجد الجامع بقرطبة مائة وتسعة وخمسين أئمة، ومقرئين وأمناء ومؤذنين، وسدنة، وموقدين وغيرهم من المنصرفين (ابن عذاري،1983م، ج2،

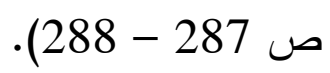

يعتبر الخليفة المستتصـر أول من أقام مبدأ مجانية التعليم بشكل رسـي في الدولة، حيث أمر بإنشـاء عدد من الكتاتيب، وجعل التعليم فيها بالمجان لأولاد الفقراء والمحتاجين، فكانوا يتلقون فيها تعليمهم الأول، أي كانت أنثـــبه بالمدارس الإبتدائية في يومنا هذا، وتعهد بالإنفاق عليها ودفع رواتب المؤدبين وطعامهم، فيقول ابن عذاري:" ومن مســـتحســنات أفعاله وطيب أعماله، اتخاذه المؤدبين يعلمون أولاد الضــــفاء والمساكين"( ابن عذاري، 1983،ج2، ص 248- 249؛ عنان، 1997م،ج1، ص 507 ؛ حسنين،2013م، 
ص 7 ؛ البشـــري، 1982م،ص 146؛ ريبيرا، 1994م، ص 15؛ ،بدر ،د-ت، ص 110؛ وائل صـــالح، 2019م،مج2، ع6، ص 117 - 118) فلقى المدح من الشعراء: فقال ابن شخيص(5) توفي قبل الأربعمائة (ابن عذاري،1983م، ج2، ص 240 - 241؛ الفهري، 2016م، ص 183) : وسـاحة المسجد الأعلى مكلة مكاتبًا لليتامى من نواحيها لو مكنت سور القرآن من كلم نادتك يا خير تاليها وواعيها وقد سـار المنصــور بن أبي عامر على نهج الخليفة الحكم فكان رغم مشــــل الُملك يحضــر دروس العلم وحلقات الدروس، ويسـتقفـر من الطلاب عن مشـاكلهم، ويحثهم على الاسـتزادة من العلم، ويمنح الأموال للطلاب المتفوقين منهم تشجيعًا لهم (بوشتيش، 1993م، ص 59 ؛ التواني، 1967م، ص 663 ؛ الأخضر ، ع. 16، ص 91.) - جهود الدولة في التخلص من الجراد: اهتم بعض الحكام بمشـروع تجميع الجراد والتخلص منها، بسـبب تأثثره السـلبي على المزروعات حيث كان يكتســــح الأراضـــي، فيهلك الثــار ويؤدي إلى معاناة الفلاحين وخاصــــة فقراء الفلاحين الذين تهلك محاصـيلهم فيضـيع عليهم الموســ بدون أي مقابل مادي، فمثلًا عندما اجتاحت أسـراب الجراد الأندلس عام

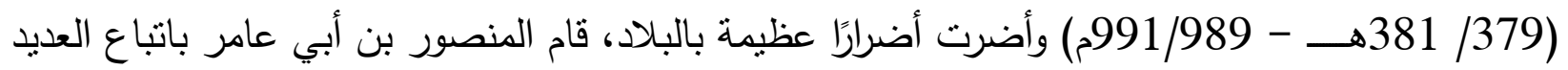
من الطرق للتخلص منه، فبذل الأموال للناس وأمرهم أن يجمعوا الجراد كل حسب قدرته وهيأ له مكانًا خاصًا بجانب الســـوق لبيعه، فكان لهذا التذخل من قبل الدولة أهمية كبرى من جانبين أولاً: التخلص من أضـــرار الجراد عن طريق تشـجيع الناس على جمعه وقتله، ثانيًا: وجود عمل يدر على أولئك العمال أموالاً وطبيعي أن الذي قام بهذا العمل الفقراء، فضمن لهم باب رزق (ابن عذاري، 1983م،ج3 ، ص 115).

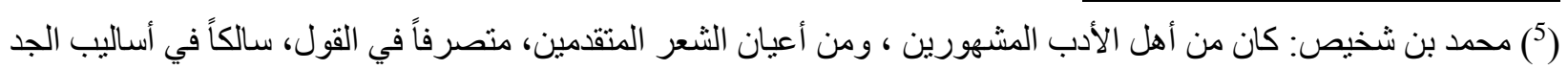

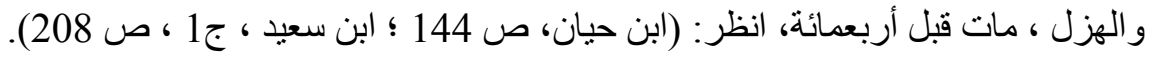


وفي أيام المرابطين أدركت الدولة خطورة الجراد، فنجد علي بن يوسـف بن تاثـفين برسـل رسـالة إلى عماله في الأندلس، يحثهم على جمعه، تلافيًا لضرره فيقول: " وانظروا إليه وباله العون...فاخرجوا إليه الغفير ولا يتخلف الكبير منهم ولا الصغير فجدوا في إطفاء هذا الجمر (أي الجراد)...." ( سليمان الهرفي، 1985م، ص 283 - 284

- السماح للضعفاء والفقراء برفع شكواهم: وقد تعددت أوجه المسـاعدات والدعم من جهة الحكام للفقراء، فثـملت رفع المظالم ودفع الضـرر بسمع الثـكوى من الضــفاء، ومثال ذللك: ما فعله الأمير عبد الرحمن الداخل الذي كان يجلس للضــفاء ويسـمع منهم، وينظر بنفسـه في قضــاياهم، فكان يســح للفقراء بالاخول عليه لرفع مظلمتهم دون مشـقة (المقري، 1988م، ج1 ، ص 332 ؛ فرغلي، 2006م، ص 66)، ومن دلائل ذلك رفع أحد فقراء العامة شكوى ضـ

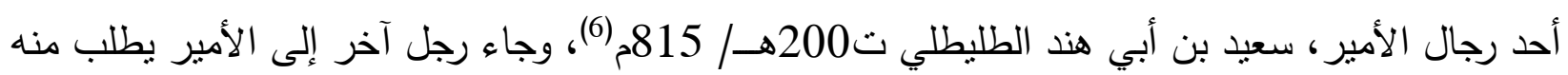
إنصافه (المقري، 1988م، ج2، ص 37)، فهذا إن دل على شيء فهو يدل على سماحة الأمير مع الضعفاء والمسـاكين ومحاولة سـماع شـكواهم وحل مشـاكلهم، وفي السياق ذاته برز دور ابنه هشـام بن عبد الرحمن، الذي تظلم له شـــــص من أحد عماله، وقد أثـــفق على حال الرجل وفقره أحد رجال الأمير المقربين فرفع الثكوى للأمير، فأرسل إلى الثشاكي، وقال له: احلف على كل ما ظلمك فيه، فإن كان ضربك اضربه، هنكا سـترك فاهتك سـتره أو أخذ مالك فخذ ماله إلا أن يكون أصساب حدًا من حدود الله " ( ابن عذاري، 1983م، ص 244 ؛ مجهول، 2007م، ص 179- 173؛ مجهول، 1989م، ص 109؛ اللبودي، 2014م، ع1، م24، ص 339)، فكان الأميرهشام بذلك من أثند الناس قمعًا لتسلط عماله ورجاله، فكان يذهب مذهب عمر بن عبد العزيز - رضـــي الله عنه- في العدل بين الناس وبالمنل كان الأمير عبد الرحمن بن الحكم يســـع

(6) أبو الهند الطليطلي هو عبد الرحمن بن هند الأصبحي من أهل طليطلة يكنى بأبا هند سمع من مالك بن انس، وكان مكرماً وقد استوزره بعض الحكام مات 200 هـ انظر ( ابن الفرضي، ج1 الطن ، ص 155 - 156). 
شكوى الفقراء بنفسه، كسماعه لثكوى حسانة التميمية(7)، التي جاءت إلى الأمير نتكو من والي إلبيرة جابر بن لبيد، الذي سبطر على أملاكها الممنوحة لها من الأمير الحكم بن هشام؛ فما كان من الأمير عبد الرحمن إلا أن أنصـف حسـانه وعزل لبيد ورد إليها أموالها (المقري، 1988م ، ج4، ص 167 - 168)، كما كان الأمير عبد الله 275-300هـ/ 888- 912م يستمع إلى شكوى الفقراء والمظلومين، فقيل أنه فتح بابًا للعامة، لتلقي رقاعهم وبذلك لا تحجب مظالمهم عنه فكان يؤمن عنده الخائف حتى أنه لا يوجد فقير لا يســنـيع الوصول إليه (ابن عذاري، 1983م، ج2، ص 280؛ ابن الخطيب، د-ت، ص 24 ؛ عنان، 1997م، ج1، ص 346 - 347)، وقد عزل والي إلبيرة جهور بن عبد الله بسبب تظلم الرعية منه وقد وصـف سـلمان بن

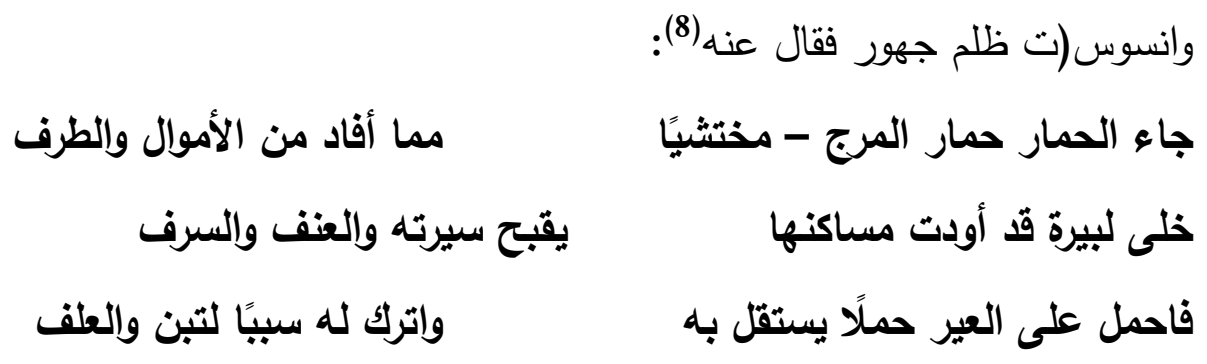
وفي الإطار ذاتة حرص الحكم المسـتـصـر علي حماية الرعية من ظلم الولاة وهو ما ظهر من خلال العديد من السـياسـات، منها نظام الرقابة علي العمال من خلال إرسـال مندوبين لاسـتطلاع أخبار الرعية أوجلب ممثلين عن الرعية إلى حضرته لسؤالهم عن سيرة العمال (ابن عذاري، 1983م، ج2، ص239)، وكان لعبد الملك بن أبي عامر دور في السـماح للضــفاء برفع مظالمهه، فقد كان يخاف الله في أفعاله مراقبًا لله محبًّا للصــالحين يحاول نثـر العدل ونصــرة المظلومين ويقمع أعداء الدين (ابن عذاري، 1983م،ج3، ص3 ؛ مجهول، 1983م، ص 172)، ورغم أحداث الفتتة القرطبية إلا أن نصـــرة المظلومين كانت حاضــرة في سـياسـات أحد خلفاء تلاك الفترة وهو على بن حمود الذي جلس بنفسـه للمظالم، وهو ما أنزّ على إقرار العدل

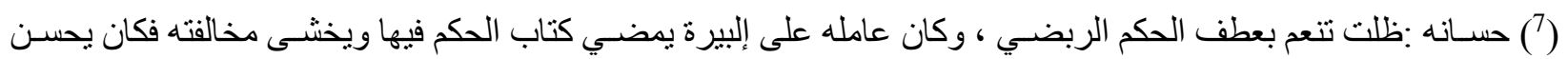

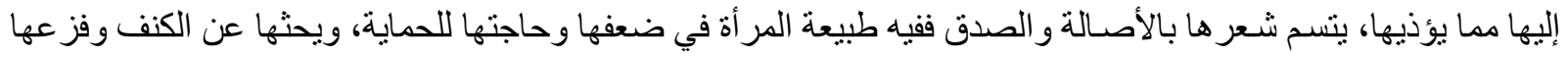

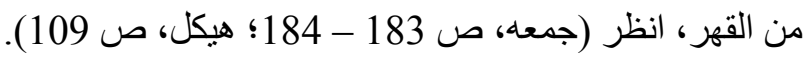

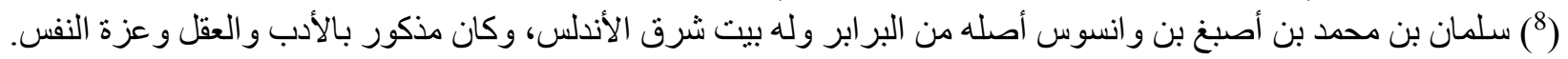

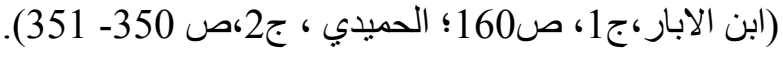


(ابن عذاري، 1983م،ج3، ص 30)، وفضـلًا عن السـياســات العادلة التي أقرها يوسـف بن تاشـفين، فقد شهدت إحدى رسائل علي بن يوسف إلى قاضي مالقة عام 523 هـــ- 1128م علي تحرية العدل وإحقاقه الحق، والنظر في شكاوى العامة وتظلماتهم (مكي، 2016، ص117؛ عنان، 1997م، ج3، ص 431).

- دور بعض الحكام في تخفيف الضرائب ورفع المفاسد: كان لبعض الحكام دور كبير في كبح جور وظلم الولاة الذين تعددوا فرض مزيد من الضـــرائب على الرعية، حيث حاول البعض منهم التخفيف عليهم، فمثنًا كان الأمير محمد بن عبد الرحمن مهنمًّا بمصـــالح المسلمين والتخفيف من معاناة الرعية من الضرائب التي استشرت بسبب كثرة الحروب، والتي دائيًا ما تعود بالسلب علي كل أوجه النشـاط الاقتصـادي من زراعة وتجارة وصـناعة، ومن ثم قام بالتخفيف من الضـرائب المفروضـــة (ابن عذاري، 1983م، ج2، ص 109 ؛ عنان، 1997م، عصــر الخلافة، ص 307 ؛ بدر، 2010م، ص 175)، لاسيما أيام المجاعات، فعندما اثتنكى الرعية ثقل ضريبة العشور أثناء المجاعة التي شملت السنوات 251هـ/ 865م إلى260هـ/ 873م، قام الأمير بتخفيف جزء من هذه الضرائب حتى يستطيع الناس مواجهة الأزمة التي عانوا فيها ضــروب الفقر والبؤس والحرمان (ابن الفرضـي، 1989م، ج1، ص 346 ؛ ابن الآبار، 1985م، ج6، ص 48)، وبالمثل منع الخليفة الناصر جمع الضرائب أو الزكاة من بلدة طرطوشة ؛ عونًا لهم بسبب ما حل ببلدهم من خراب على يد النصارى (ابن حيان، 1979م، ج5 ، ص 68

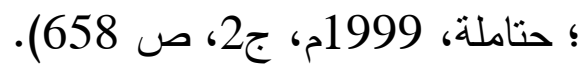

كما خفف الخليفة المستتصر أيضًا من الضرائب المفروضة علي الرعية وأسقط عنهم الخراج دعمًا منه لهم، وفي السياق ذاته رفع الخليفة الحكم المستتصـر بعض المغارم عن الرعية، فأسقط سـس مغرم الحشـ الواجب أدائها على سـائر الرعية في كافة بلاد الأندلس عام 364هــــ/ م914م (ابن حيان، 1982م، ج3، ص207 ؛ ابن عذاري، 1983م، ج2، ص249)، وكذلك نجد المنصـــور بن أبي عامر ينقرب إلى الفقراء بإلغاء ضريبة الزيت التي كان يتذمر منها الفقراء كثيرًا، حيث أثنار الحاجب جعفر المصحفي بذللك، فأصبح 
محبوبًا لدى الفقراء لإهتمامه بحوائجهم ودعمه لهم (ابن عذاري، 1983م، ج2، ص256)، وسار عبد الملك المظفر على نهج أبيه في الإحســاس بمعاناة الفقراء والمســـاكين، فأعفاهم من ســـس الجباية وكثير من الضرائب والمكوس الأخرى (ابن بسام، 1997م، ق4، ج1، ص 78 ؛ ابن عذاري ، 1983م، ج3، ص 34 ؛ ابن الخطيب، ص 89)، ونظرًا لما حل بالناس أيام الفتتة القرطبية، قام يحيى بن علي بن حمود عام (412هـ - 1021م) بإسقاط نصف الخراج عنهم (مجهول،1983م، ص208). أما ملوك الطوائف فقد أتقلوا كاهل الرعية بالضرائب من أجل مصالحهم الثخصية، ومع بداية عصر المرابطين اهتم يوســ بن تاثـفين بالسـياسـات المالية، فأنقذ الرعية من كابوس الضـرائب الباهظة التي لا تخضــــع لنظام معين في زيادتها حيث التزم بالضـــرائب الثـــرعية، وقام بتثــــيع التجار ووفر لهم حياة

$$
\text { كريمة(المراكثي، 2006م،ص226-235). }
$$

ثالثا: دور مؤسستي القضاء والحسبة في دعم الفقراء: - عدل القضاة بين الفقراء والأغنياء في الأحكام: حرصـت المؤسسـة القضـائية في الأندلس على المسـاواة بين الفقراء والأغنياء في تتفيذ الأحكام، حيث وجد في الأندلس عدد كبير من القضـاة الذين لا يخافون في اله لومة لائم وتجري أحكامهم على جميع الناس بجميع طبقاتهم، وهو ما خلق النقة في نفوس الفقراء وأنثـعرهم بعدالة القضــاة، ومن هولاء القضــاة القاضـي هي معاوية بن صالح، الذي أسند إليه الأمير عبد الرحمن الداخل القضاء، فكان عدلًا ثقة في أحكامه (الحميدي، 1989م، ج2، ص540-542)، وبالمثل يضـرب لنا القاضـي نصـر بن طريف اليحصبي أروع الأمتلة في تتفيذ العدل والمساواة بين الفقراء والأغنياء حتى لو كان أقرب الأقربين إلى السلطان، ويتضح ذلك من قضية حبيب القرشي الذي شكا القاضـي نصـر إلى الأمير عبد الرحمن بن معاوية، بسبب حكم القاضـي عليه في ضيعة أثبت اغتصابها؛ فطلب القرشي من الأمير تأخير الحكم وبالفعل طلب الأمير عبد الرحمن من القاضي نصر تأجيل الحكم على حبيب ولكنه أنفذه وعندما علم الأمير بتتفيذ الحكم وبخه وقال له كيف للك أن تصدر حكمًا قد أمرتلك بتأخيره فقال له : " أن الرسـول-صلى الله عليه وسلم - كان ينفذ الحق على القريب والبعيد 
والثــريف والدنيء، وقال له أيضًا وأنت أيها الأمير كيف للك أن تتحمل على بعض رعيتك على بعض....

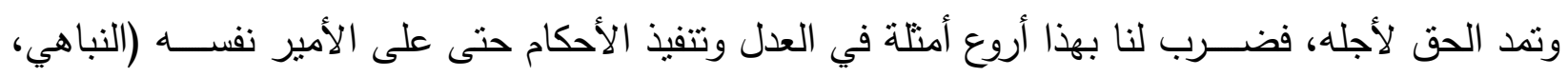

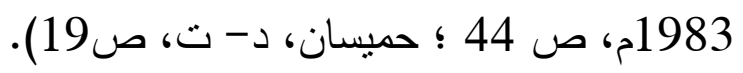
وعلى شاكلة القاضي بن طريف كان القاضي مصعب بن عمران الهذاني(9)، الذي أقره الأمير هشام بن عبد الرحمن على القضــاء، فعرف بصــلابته في الحق وتتفيذ الأحكام ودعمه للفقراء والمحافظة على أموال الأيتام، ومصــق ذلك أن العباس بن عبد المطلب المرواني اغتصـب ضــيعة رجل فقير من جيان، ثم لقي الفقير حتفه، وترك أيتامًا صغارًا، وعندما كبر هؤلاء الأيتام وسمعوا بعدل القاضـي مصعب بن عمران جاعوا إليه ورفعوا دعوتهم، فما كان من القاضي إلا أن أحضر العباس وأثبت حق الأطفال، ففزع العباس إلى الأمير

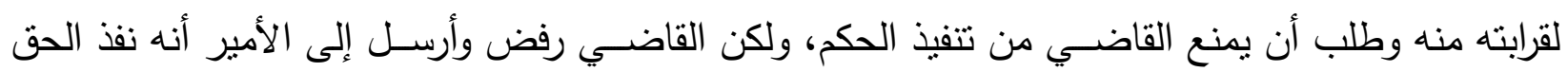
الذي سوف يسأل عنه أمام الله سبحانه وتعالى (النباهي، 1983م، ص46-47). وهذه الرواية تدل على أمرين أولاً: عدل القاضي الذي ساوى بين الفقراء والأغنياء وانتصف للفقراء حتى من الطبقة العليا في المجتمع، ثانيًا استقلال القضـاء عن السلطة التنفيذية، فلم يتعنت الأمير ولم يصر على تغيير حكم القاضي رغم صلة القرابة التي تربطه بأحد المتخاصمين، فقد قيل عن القاضي مصعب أن الأمير كان يؤيده ولا يسمع لأحد يتكلم عنه بسوء وينفذ أحكامه حتي لو كانت على أقرب أحبابه (النباهي، 1983م، ص46) وبالمثل اشتهر القاضي الفرج بن كنانه بنصرته للمستضعفين، وصلابته في الحق، وهو ما يتضح في سلوكه اتجاه أحد جيرانه الذي أُتُهم بالضلوع في الثترة ضد الحكم بن هشام، فعندما أرسل الأمير الحكم رجال الثـرطة للقبض على جاره اشـتبك معهم القاضـي كنانه ودافع عن جاره باسـتماتة، وعندما لم تجدي محاولاته ذهب إلى الأمير الحكم وتظلم إليه وشـهـ بأن جاره مظلوم فعفا عنه الحكم وعفا أيضًا عن باقي أهل قرطبة

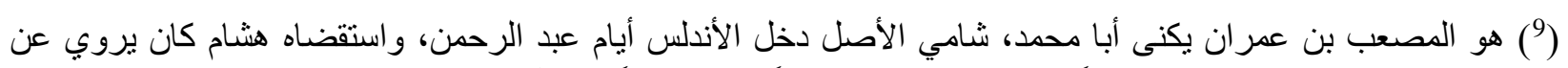

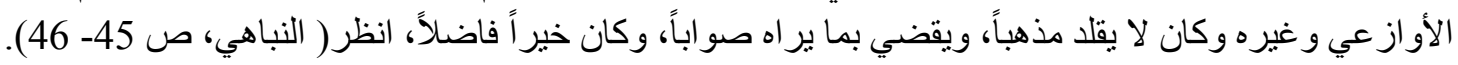


فكان بذلك القاضي نصرة لهؤلاء المستضعفين ومنقذًا لهم من الهلاكى(10)"،وقد تورع عدد من الفقهاء والعلماء عن تولي منصب القضاء، إلا أن البعض أجبروا في بعض الأحيان علي ذلك ومنهم القاضي محمد بن بشير المعافري ت 198هـــ/ 813 م، الذي استقضاه الحكم بن هشام بعد أن أجبره على ذلك، ولكنه وضع شروط تضــمن اســقتلاله وتتفيذ احكامه والمســاواة بين الفقراء والأغنياء، ومنها نفاذ حكمه على أي أحد من رجال الأمير حتى حارس السوق، بحيث إذا أحس بالعجز أو أي نوع من التقييد له، بُعفى من المنصب، وأن يكون رزقه كفافًا من مال الفيء، فقد اثـتهر القاضـي محمد بن بشـير بصـلابته في الحق، والمسـاواة بين الفقراء والأغنياء (ابن حيان، 1994م، ص 193). وعلى شاكلة القاضي بن كنانة كان القاضي سليمان بن الأسود الغافقي، فقد اشتهر بصلابته في الحق والانتصار للمستضعفين حتى وإن كانوا على غير ملة الإسلام، ومن ذللك إنصافه ليهودي ضعيف، استولى أمير ماردة محمد بن عبد الرحمن علي جاريته، حيث واجة القاضــي الأمير محمد بالدعوة المرفوعة ضـــه، فأنكر فاضطر القاضي إلى التوجه إلى أبيه عبد الرحمن الأوسط حاكم الأندلس فأنصفه أمير الأندلس ومكنه من إنفاذ حكمه لصـالح اليهودي، وهو ما جعل القاضـي محل إعجاب الأمير محمد، حتى أنه عندما تمت له البيعة بعد أبيه أقره على القضـاء، وبالمنل أنفذ القاضـي نفسـه حكمه على بدران الصقلي مولى الأمير محمد بن عبد الرحمن، الذي تعدى على دار امرأة فضــلًا عن تغافله عن طلبها لحقها، وهو ما دفع القاضــي إلى الانتصاف لها ومعاقبة مولى الأمير، الذي بادر بالثكوى للأمير إلا أن الأمير محمد رده قائلًا له إذا سألتنا حاجة للك نجيبها، ولكن لا نعصسي القاضـي في أمر من أوامره، وقد أغلقنا هذا الباب فلا نجيب له أحد من

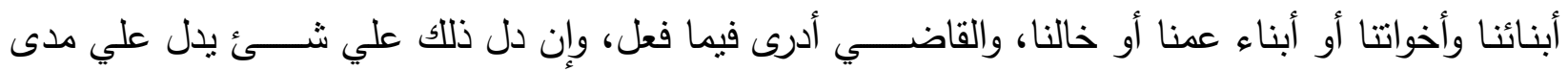
استقلال القضـاة خلال عصر الإمارة، واحترام السلطة التنفيذية لأحكام السلطة القضـائية التي حافظت على

(10) هو الفرج بن كنانه من الفقهاء المعدودين بالأندلس في حدود القضــاة رحل إلى المشـرق وسـع من عبد الرحمن بن القاسـم

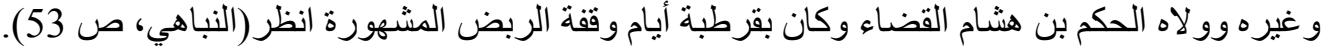


حقوق المسـتضـففين وأنصـفتهم حتى من كبار رجال الدولة وأفراد الأسـرة الحاكمة (الخشـني، 1989م، ص

$$
173 \text { - } 181 \text { ؛ النباهي، 1983، ص } 56 \text { - 59: 5). }
$$

وفي السياق ذاته كان القاضي أحمد بن بقى بن مخلد ت(324هـ/935م)، عادلًا صلبًا في الحق فيروى من عدله أنه عندما أراد الناصــر شـراء المجشـر من أحباس المرضـى وأخذ برأي القاضــي ابن بقي (11)، فقال القاضـي لا حيلة عندي والحبس أولى بحفظ حرمته ولم يجعل للخليفة سـبيلًا لشـراء المجشـر (12)، كما عرف برن عن القاضــي عقبة بن الأســوار الذي تولى أيام الأمير عبدالرحمن أنه كان من أهل التحري للعدل، اثــتهر بالتواضـع وحسن السيرة واستقامة أحكامه (ابن حيان، 1994م، ص193)، وكان القاضي سـيد بن المنذر يحرص على المسـاواة بين الفقراء والأغنياء ويعتني بالفقراء في حكمه فلا يحيف عليهم أبدًا مهما كان الأمر ، فذات مرة أراد الناصر شراء دار كانت بقرطبة لأطفال أيتام فقيل أن البيع لا يتم إلا بتولي القاضي أمر البيع، فأرسل الخليفة الناصر إلى القاضي سعيد بن المنذر فقال : البيع لا يصح إلا في وجوه، منها الحاجة والوصي الثـــديد والوهي والغبطة، أما الحاجة فلا حاجة لأولاد الأيتام للبيع، وأما الوهي فليس فيها، وأما الغبطة فهذا مكانها فأظهر الخليفة الزهد في شــرائها، فأمر القاضــي بهدم دار نجدة، وذللك لأن بيع الأنقاض ذات قيمة أعلى مما قُومت به للسلطان، ولما علم الخليفة لأمر القاضي، لامه فرد القاضي عليه: أخذت بقوله تعالى: "

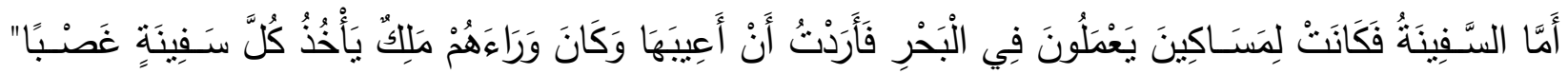
فأعجب الخليفة به وأمضسى حكمه،شكره علي أمانته (المقري، 1988م، ج2، ص 16 - 17). كما اثتهر

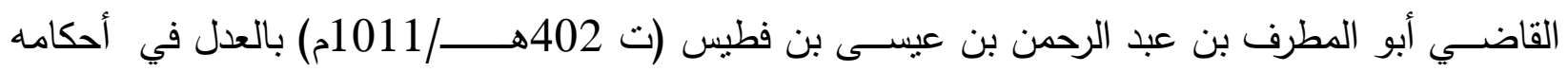

(11) هو أحمد بن بقي بن مخلد أبو عبد الله سمع من أبيه و هو صغير وتركه أبوه و هو ابن أربعة عشر سنة،كان زاهداً فاضلاً،

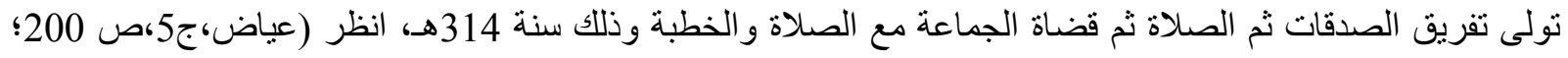
النباهي، ص 65 65).

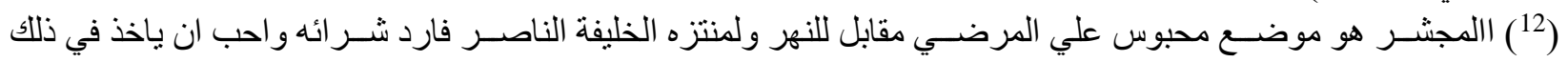

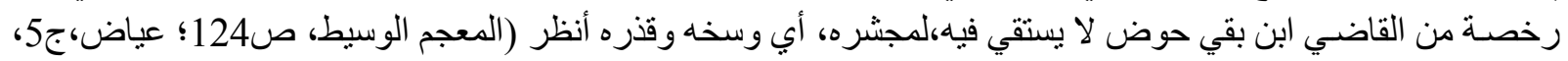
ص200-209). 
والصلابة في الحق ونصرة المظلوم وقمع الظالم وله في ذلك أخبار مأثورة(13)، وبالمنل ضرب القاضي محمد بن عبد الله بن عيسى أبلغ الأمثلة في نصرة المظلومين والضعفاء وقمع الظالمين فقيل " لم يطع شريف في حيفه ولا يأس فقير من عدله"، استقضاه الناصر على قرطبة عام (326هــــ 937م)، وولاه أيضـاً قضاء إلبيرة وأمانة الكسور والبيطرة على عمالها فكان لا يُظلم أحد من أب جانب إلانصره (النباهي، 1983م، ص 60 62 62؛ عياض ، 1983م، ج2، ص 84 - 86)، اشـتهر أيضـاً القاضـي محمد بن السـليم (ت367هـ

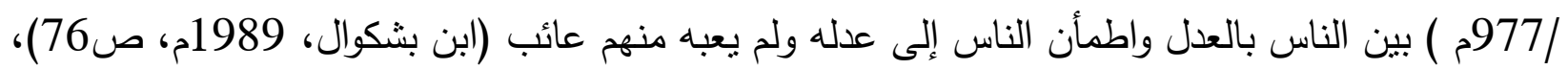
وبرز دور القاضي الحسن بن عبد الهه الجذامي (ت392هـــ/1001م) في الرفق بالضعفاء والثدة على أهل الأهواء (ابن بثــــوال،1989م،ص282-84). وكذلك عرف عن قاضـــي إلبيرة أبي عيســى بن عبد الله (ت346هـ/ 957م) نصرته للضعفاء واتصافه بالعدل (عياض، 1983م، ج2، ص90)، ومن قضاءة إلبيرة

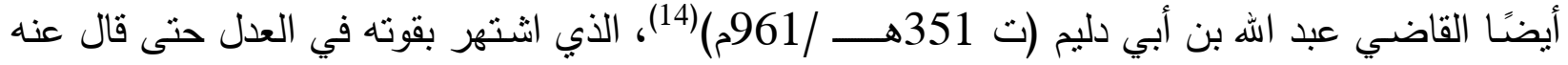
الحكم ما وصلني عنه زلة قط (عياض، 1983م، ج2 ، ص 107 - 109). كما ورد عن القاضي محمد بن الحسن الجذامي ت462هـ /1069م (15)، قاضي مالقة رفضه لتولي القضاء ولكنه عندما عزم الأمير يحيى الملقب بالمتعلي على توليته الأمر، وافق القاضــي ولكن بثـرط أن يكون له النظر في ولاة الكورة وسـائر المشـتغلين بها، حتى لا يجري حيف على أحد في ناحية من نواحيها وأنفذ ذلك وأمضناه وكان حازمًا، صـارمًا، عدلًا في أحكامه، ودعمًا لاستقلاله فلم يأخذ على القضاء أجرًا من بيت المال

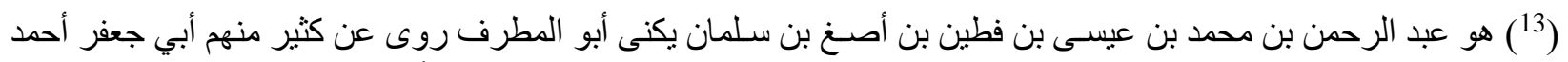

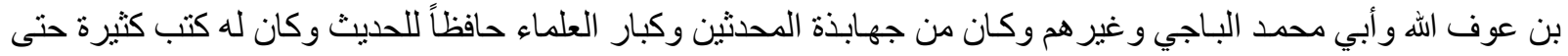

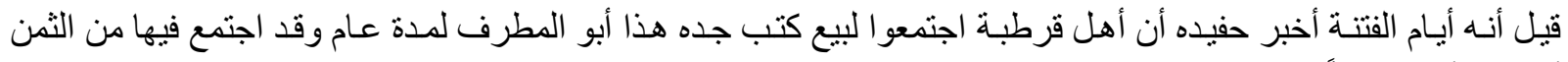

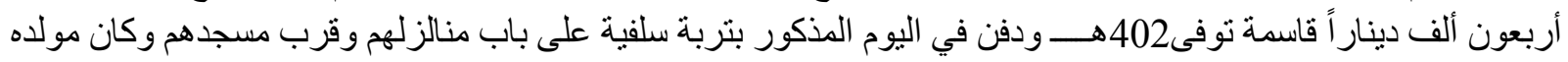

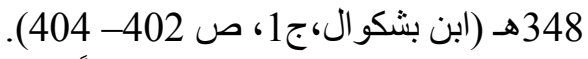

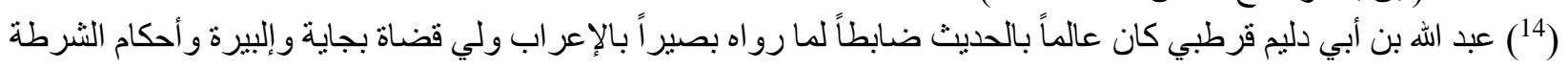

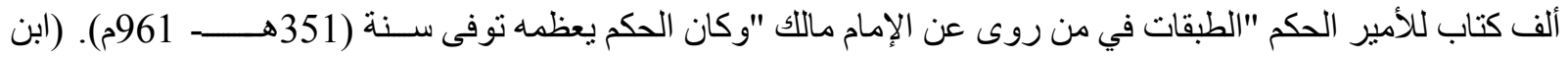

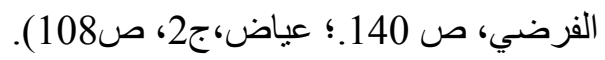

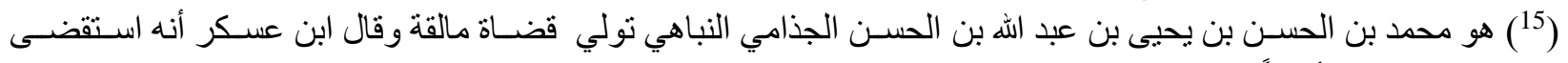

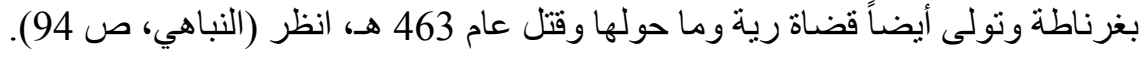


طيلة حياته، فقيل كان صلبًا في الحق لا يخاف في اله لومة لائم (النباهي، 1983م، ص 90)، ولم يختلف عنه القاضي محمد بن سليمان الأنصاري المالقي ت 500هـ/ 1106 م فقد تولى القضاء مدة في مالقة فسار فيها بأجمل سيرة في العدالة والنزاهة ( النباهي، 1983م، ص100)، وكما ذاع صيت القاضي أبي عبد الله محمد بن الحاج(16) ت529هــ/ 1134م الذي تولى القضاء في قرطبة مرتين، ولم يحفظ له جور في قضية ولا ميل بهواه ولا إصغاء إلى عناية. وقد عرف عن القاضي عبد الله بن عمر بن أحمد الوحيدي(17) (ت542هـ/1147م) الذي وَلِيَ القضاء برية سنة 531 هـ /136م التسوية بين الفقير والغني فقام بأعباء القضاة أجمل قيام وكان لا يتقاضى أجرًا على القضـاء، وكذللك كان قاضـي إثـبيلية أبو بكر بن العربي المعافري (ت 543هـــ/ 1148)، من أهل الصلابة في الحق والثدة والقوة على الظالمين والرفق بالمساكين (النباهي، 1983، ص105) وكذلك كان القاضـي أبو عمران موسـى بن حماد شـديدًا في تتفيذ العدل مترفقًا بالضــفاء اسـتقضــاه يوسف بن تاشفين في عدة جهات وكان آخر قضاءه في غرناطة (ابن بشكوال، 1989م،صوبه). - الاعم المادي من قبل القضاة لشرائح الفقراء والمعوزين: نالت شــريحة الفقراء اهتمام القضـــاة حيث عملوا على تحســين أوضـــــهم المادية من خلال تقديم الصدقات، فقد عرف القاضي عبد الله بن حسين المعروف بالسندي (ت 335هـ/ 946م ) بأنه كثير الصدقة على الفقراء والمساكين (عياض، 1983م، ج6، ص 166)، ومنلة القاضي أبو المطرف المعافري (ت407هـ

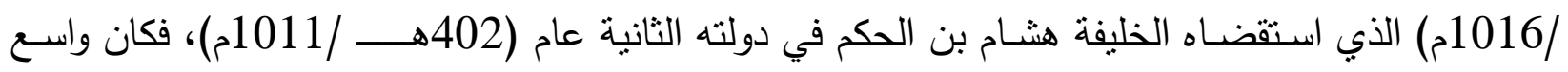

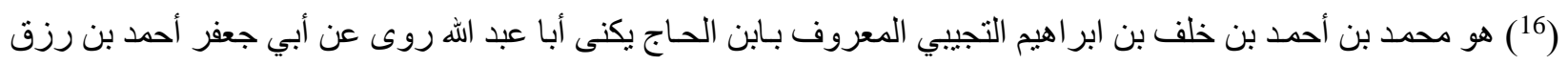
الفقيه وتعلم وسمع الكثير منهم عبد الله بن خرج الفقيه وأبي الغساني و غير هم مولده 458 هـ هـ وتوفى 529 هـ هـ ، انظر( النباهي، ص (102) (102) (17)

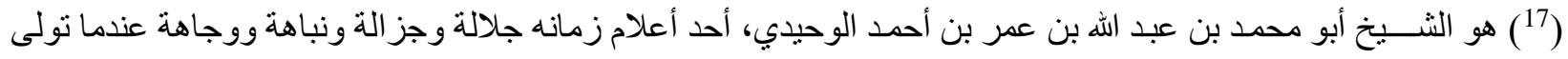

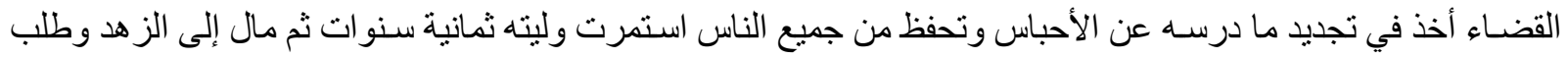

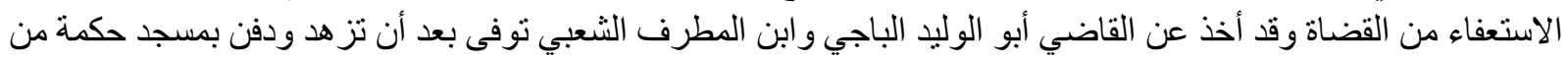

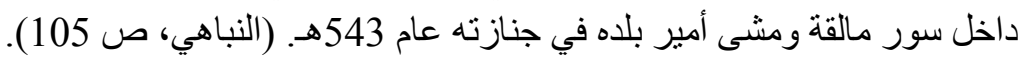


العطاء والصــدقة للفقراء والمســاكين، حتي عندما عزل عن القضـــاء شـكر الله تعالى فأخرج مدًا من القمح وتصدق به (البيلي، 1993م، ص165)، ويبدو أن ما اتسم به عصر ملوك الطوائف من الإحجاف بالرعية وعدم الالتفات لأوضـاعهم المادية وإثقالهم بالأعباء، هو ما دفع كثيرًا من القضـاة إلى محاولة التخفيف عن كاهل هؤلاء الفقراء والمعوزين ومن أولئك القضاة، القاضي خلف بن أحمد بن خلف الأنصساري الذي يعرف بـ "الرحوي" المتوفى440هـ / 1048م الذي كان فاضلًا ورعًا كثير الصدقة على الفقراء والمساكين (ابن بشكوال، 1989م، ج1، ص 267 ؛ خلاف، 1984م، ص 596 ؛ ارسلان، 1936م، ج2، ص 8). كذللك القاضي أبو الحسن النباهي (ت463هـــ/1070م) قاضـي مالقة الذي أوقف معظم كتبه على جامع قرطبة وتصــدق بالكثير من المال على الفقراء والمســاكين (النباهي، 1983م، ص 90 - 91 ؛ ابن الخطيب، 1973م، ج1، ص 81)، وكان القاضـي محمد بن أصــنغ بن المناصـف يعيل كل يوم أكثر من ثلاثمائة بيت من الفقراء والمســاكين، ورغم أنه كان يملك ضــياعًا واسـعة يحرث فيها ثمانمائة زوج إلا أنه تصــــق بجميع ذلك ولم ييقَ له إلا ما يتعيش منه (ابن بشــكوال، 1989م،ج2، ص 319)، وحذا حذوهم القاضي محمد بن أصبغ بن محمد الأزدي (ت536هـ/1141م)، الذي كان مشاركًا بجاهه وماله، كثير البر بـالناس (ابن بثــكوال، 1989م، ج3، ص 850 - 851)، ومثلـه القاضـــي أحمد بن محمد بن فرج الأنصــاري(ابن بشـكوال، 1989م،ج1، ص 118)، والقاضـي عبد الرحمن بن بحيى بن صـاعد بن وثيق قاضـي شـذونه (عياض، 1983م،ج7، ص 162)، والقاضــي أبو القاسـم أحمد بن محمد اللخمي الذي بلغ منزلة عالية فقيل كان شــريفًا كثير الصـــدقة على الفقراء والمحتاجين (عياض،1983م،ج5، ص 189 ـ 190)، والقاضي سعيد بن عمران بن شرف الذي تصدق بأكثر ماله (ابن الفرضي، 1989م،ج1،ص 292

$$
\text { ( ) باض، 1989م،ج7 ، ص } 27 \text { - 28). }
$$

وإلى جانب عدل القضاة في الأحكام لهصالح الفقراء وتقديم الدعم المادي لهم من خلال الصدقة، سعى بعض القضـاة إلى التوسط لدى الحكام لحل مشـاكل الرعية وقضـاء حوائجهم فهذا القاضـي الحبيب أحمد بن محمد بن زياد بن عبد الرحمن بن زهر اللخمي الذي تولى القضاء عام 261هــــ/874م، كان مهنمًا بقضاء 
حوائج الناس بماله وفي خدمته كان حسـن المداراة لطيفاً في الأمور (الخشـني، 1989م، ص 204- 205؛ عياض، 1989،ج5، ص 189- 194)، وعلى الثناكلة نفسها كان القاضي محمد بن زياد ت 367هـ/977م من أهل الزهد والغنى، يتبارر في قضــــاء حوائج الناس ،فكان بابه مفتوحًا للمحتاجين، يبيت عنده كل ليلة عشرة يأكلون من طعامه (عياض، 1983م، ج5، ص 189- 190؛ الخشني، 1989م، ص 205)، وكان أيضًا القاضي عبد الرحمن بن محمد بن أحمد بن المشاط 367هـ/ 977م، قاضي بلنسية معتنيًا بأمر الرعية يقوم بقضاء حوائجهم (شكيب أرسلان، 1936م، ج2، ص 40). وأيضًا القاضـي عبد الله بن حمدين الذي قطع الضــرائب والمعاون على أهل قرطبة وسـن كل طريقة جميلة وسيرة حسنة لأن ابن تاشفين كان لا يخالفه في شيء (ابن القطان،1990م، ص508)، وضرب لنا القاضي عبيد الله بن عيسى بن حسون المالقي (ت505هـــ/1111م)، في قضاء حوائج الأيتام والفقراء أروع الأمتلة فكان " قبلة للأيتام، غمامًا للأنعام، ومفاخر يتباهى به النثر والنظام، وتتبارى في طلبه الســيوف والأقلام "، وكان يطوف الثــاكرين ببابه حيث مدحه الثــعراء بذللك فقد كان لا يقفل بابه في وجه أحد من القاصــدين وكانت صـدقاته دائمًا في السـبب في نعش العبد القن والفقير الحر فكانت يده الأيدي التي ترفع الضـيم عن الفقراء والمساكين (ابن عسكر وابن خميس، 1999م،ص 291). - دور القضاة في زمن الكوارث والمحن: برز دور القضاة في دعم الفقراء والمحتاجين لاسيما أثناء الكوارث والمحن، فمن خلال مخالطة القضاة لأفراد المجتمع الأندلســي اطلعو علي أحوالهم وعلموا احتباجـاتهم، فكان لهم دور في دعم الفقراء أوقات الأزمات والمجاعات، ومثال ذلك القاضي محمد بن عيسى الأعثى (ت 220هـ، وقيل 222هـ)، الذي كان كثير الصدقة شديد العطف على الفقراء والمساكين أيام المجاعات والثدائد، فذات سنة اشتدت الأزمة بالناس وغلت الأسعار وعم الفقر، فأمر القاضي محمد بن عبسى منادي ينادي في الناس " من أحب أن يبتاع طعامًا بسعر يومه بتأخر عام فيأت إلى وكيله في ذلك محمد بن موسى" فبادر الناس وأخذوا منه حتى انتهي مقدار ما أباحه لهم، ثم أمر" منادي ينادي من كل لمحمد بن موسـى عنده شـيء فقد وضـعه عنه "، وعندما سـئل 
القاضي عن فعله هذا وقيل له لو تصدقت به كان أفضل، قال: لو كان هذا لم يأخذها إلا من يأخذ الصدقة من الطوافين وشبهم، أما الآن فيأخذ منها الثريف المحتاج، والمتعفف المستور، ومن لا ينكثف لأخذ الصدقة (الخشني، 1989م، ص113 - 114؛ عياض، 1983م، ج2، ص114). وفي السياق ذاته أنقذ القاضي عبيد الله بن يحيى (ت298هـ/ 910م ) جارًا له كاد أن يُهلك هو وأهله أيام المجاعة وارتفاع الأسـعار وتوالي الأخطار بالناس لفترة من الزمن، فأرسـل القاضـي عبيد الله إلى جاره الأموال والدقيق اللازم حتى يسـطيع تخطي المجاعة (عياض، 1983م، ج4، ص 421- 423)، كما برز دور القاضـي عبد الرحمن بن عيسـى في العطف على الفقراء والمسـاكين أيام الأزمات، فقيل كان يأكل من

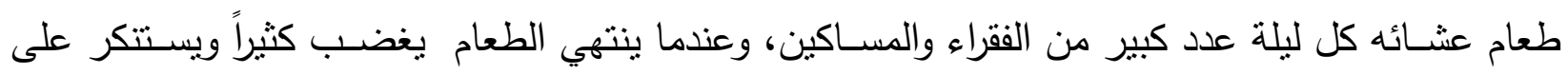
أهله أنهم لم يكثروا المرق (عياض، 1983م، ج7 ، ص 27 - 28)، كما عظم دور القاضـــي محمد بن أحمد بن عيسي بن منظور القيسي (ت496هـــ1102م ) في هذا الثنأن حيث كان يؤثر الفقراء والمساكين على نفسـه وأولاده، ففي بعض ســوات القحط والمجاعة قام بتوزيع خمسـين قفيزًا من القمح على المســاكين والفقراء، فثـــكى ابن عمه إلى الناس فعله هذا وتركه أولاده وتوزيع هذه الكمية في هذه الأزمة، ولكنه لم يهتم قائلًا بأنه أعطاها له (ابن بشكوال، 1989م، ج3، ص 803 - 804 ؛ النباهي، 1983م، ص 96). - دور مؤسسة الحسبة في مواجهة الفقر: نظرًا لارتباط الحسبة بحياة الناس الاجتماعية والاقتصادية والدينية من خلال عمل المحتسب الذي يقوم

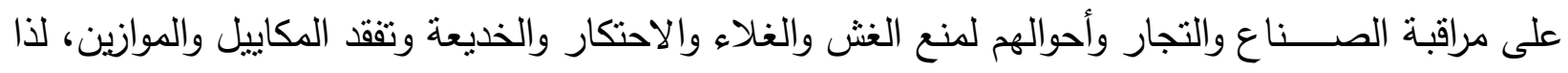
كان للمحتسـب دور عظيم في المجتمع حتى قال ابن عبدون " الاحتسـاب أخو القضـاء "، لذلك كان لابد أن يتحلى المحتسب بالنزاهة والعفة والصدق والعلم والغنى أيضًا حتى لا يلجأ إلى الرشوة (ابن عبدون، 1955م، ص 20 - 21 ؛ ابن بسام المحتسب، 2003م ، ص 285 ؛ القرشي، 1976م، ص 4)، ولا ريب فكل ذلك يصـب في مصــلحة الفقير التي تعد أولوية كبرى بالنسـبـة للمحنسـب من خلال منعه للاحتكار والغش في الأسواق، وهو ما يحمي الفقير ويسهل عليه شراء مستلزماته اليومية، في هذا الإطار كان الفقهاء يحرصون 
على أن يكون المحنسب من أهل البلد حتى يسهل عليه معرفة حالة الباعة وأوضاعهم وطرق معيشتهم، وهو ما يسـاعده في إنجاز مهامه الموكله إليه (ابن عبدون، 1955م، ص 120)، وهو نفسـه ما أوصسي به ابن عبدون (ابن عبدون، 1955م، ص 16)، وقد أولت دولة الأندلس اهتمامًا كبيرًا بوظيفة المحتســب حتى أصبح لهم في أوضاع الاحتساب قوانين يتداولونها ويتدارسونها، كما تتدارس أحكام الفقه لأنها تدخل عندهم في جميع المبتاعات "( المقري، 1988م، ج1، ص 218 - 219)، وقد أعطت الدولة المحتسـب صـلاحية إيقاع العقوبة التي يراها واجبة على من يثبت عليه الغش أو الإحتكار فكان يمشـــي بنفســـه في الأســواق، ويختبر الموازين و يرســل الصـــار لإختبار الباعة في الغش وغيره من عمليات التلاليس التي ترهق الفقراء والعامة (المقري، 1988م، ج1، ص 180)، هذا بجانب حق المحتسب في تحديد الأسعار، هذا فضلًا عن

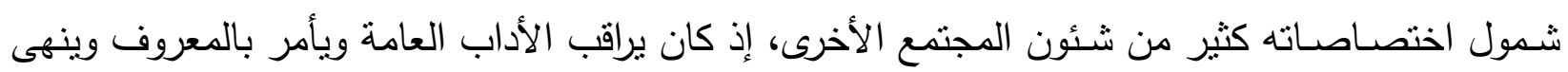

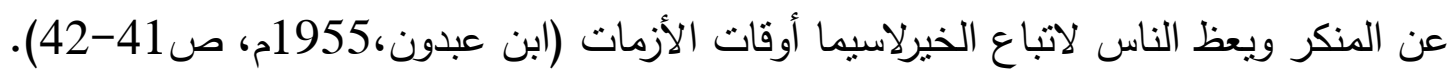
وكانت الدولة الأموية كثيرًا ما تتحرى تعيين الثـخص المناسـب في وظيفة الحسـبة وذلك حفاظًا منهم على مصــالح الناس، لذلك كثيرًا ما يتعرض المحتســب للعزل بعد مدة قليلة ويسـتنبدل بغيره، لذلك شــــت أعوام323هـ إلى326هـ تعاقب العديد من الأشخاص على وظيفة المحتسب، إذ ذكر في حوادث سنة322هـ عزل حســن بن أحمد بن عاصـــم عن خطـة الســـوق في محرم، فتولاهـا يحيى بن إدريس (ابن حيان، 1979م،ج5، ص355)، ولم يكتفِ أمراء الدولة الأموية بهذا فقط فكانوا يراقبون الســـوق بأنفــــهم، فكان

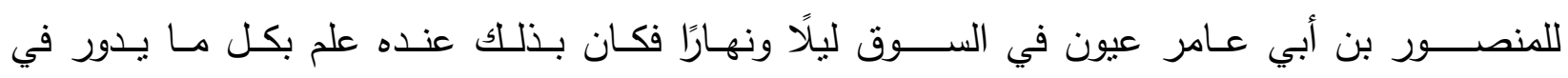
السوق(المعموري،ع 10، 2012م، ص بـ 93). وبالنســبة لنظام الحســـبة أيام ملوك الطوائف، فلم يختلف كثيرًاعن الدولة الأموية رغم الفتن والحروب والاضــطرابات والتتاحر والتنافس، ظل المحتسـب في أداء واجباته، وكان أمناء الســوق الذين يعملون معه يمدونه بكافة معلومات السـوق، وجمع المحتسـب بين الثـرطة وولاية السـوق ومنهم أبي طالب بن محمد بن مكي القيسي (ت474هـ 1081م)، فقد نولى أحكام السوق والثرطة بجانب الأحباس وأمانة الجامع (المعموري: 
2012، ص 93)، وبسـبب الأوضــــ في عهد ملوك الطوائف كثرت أعمال الغش والاختلاس في الموازين والمكاييل فتولى عدد من رجال الحسـبة عرف عنهم القوة والحزم والصــرامة منهم أبي بكر بن خلف بن بقي الذي قيل عنه كان منتدداً في الحق(ابن بشكوال،1989م، ج1 ، ص 265). أما في عصـر المرابطين هناك بعض الإثــارات التي تدل على وجود صـاحب السـوق ومنهم كتاب السقطي المتوفى في نهاية القرن الخامس، حيث أثنار إلى إهمال المرابطين وإلى نظام الحسبة وحذر السقطي من تركك شــؤن الحسـبة في يد الأمناء بسـبب كثرة التذليس والغش (السـقطي، 1955م، ص 9 - 16)، والإثارة الثانية هي ضرورة اقتصار اللثام على المرابطين دون سواهم والتي جعلت من صميم عمل المحتسب، فيقول ابن عبدون: يجب أن لا يلثم إلا صنهاجي أو لمتوني أو لمطي، فإن الحشّم والعبيد، ومن لا يجب أن يلثم يلثمون على الناس ويهيبونهم ويأنون أبوابًا من الفجور كثيرة بسـبب اللثام .... لأن العبيد أو الحشـم إذا تلثم وغير شكله حسبته رجلاً مثيلًا فتجري إلى بره وإكرامه وهو لا يتأهل لذلك " ( ابن عبدون، 1955م، ص

- الفتاوى الخاصة بالحسبة في دعم الفقراء: للفتاوى الخاصــة بالحسـبة دور كبير في دعم الفقراء، وذللك باعتبار أن الفقراء هم الثــرائح التي يرجع إليها جميع السلع المغشوشة عن طريق الصدقة، من نماذج ذلك فنتى ابن عناب على الملاحم الرديئة النسيج أن يتم تقصـيفها وتوزيعها على المسـاكين(ابن ســ، 1995م، ص 600 - 601)، لايقبل التناعب بأوزان وأسعار وأصناف الأقوات فقد أفنى بأن الخبز الناقص لو وجد في الحوانيت يؤدب صاحب الفرن بأن بتصدق على الفقراء(ابن سـكل، 1995م،ص 600 ؛ عبد الرؤوف 1955م، ص 90)، وعُوقب أيضًا من يخلط اللبن بماء أو يغش لبن البقر بالمعز وكُثـف أمره بأن يتصــدق به على الفقراء (ابن ســـ،1995م، ص601)، وأصــبحت هذه الفتوى المتعلقة بالمواد الغذائية تصــب في مصــلحة الفقراء فقد نهى المحتسـب دهن التين بالزيت، وقرر معاقبة من يفعل ذلك بالتصــدق به على الفقراء (ابن عمر، 1955م، ص 109)، وفي إطار الرقابة الحسبية على الأخذ بشـروط النظافة وحماية الناس من الأمراض قرار ابن عبد الرؤوف أنه " لا يمكن 
أن يبيع الخبز حوات ولا جزار ولا من تستقذر حرفته، ويؤمرون بتغطية الخبز بين أيديهم ويمنعون من مجاورة أهل الحرف القذرة كبائعي السـردين، وسـائر أصـناف الحوت والبياطرة والحجامين وما أثنبه ذلك " ( ابن عبد الرؤوف،1955م، ص 90)، ومنع المحتسب أيضًا أصحاب الحوانيت من احتكار السلع وأقوات الناس بحيث لا يترك أهل الحوانيت وسائر أهل الادخار أن يقتنوا شينًا مجلوبًا، منل الزيت والعسل والسمن والتين وما أثنبه ذلك، فالناس بحاجة إليه ولا يحتكرونه فقد قال الرســول - صــلى الله عليه وسـلــ- لا يحتكر الأخاطي إن احتكاره خطيئه ، ومن يفعل بعد ذلك يؤدب وتخرج السلعة من بين يدية وتطرق بين الناس وذوبي الحاجة (ابن عبد الرؤوف، 1955م، ص 88 - 89) فإذا تتبعنا الفتاوى الخاصة بالحسبة نجدها في مصلحة عامة الناس وخاصة الطبقات الفقيرة (العروس، 1997م، ص 261). رابعاً: دور المجتمع في تقديم الدعم للفقراء: - تقديم الاعم المادي أيام الأزمات والصدقات النقدية:

نالت شــريحة الفقراء اهتمام المجتمع بمختلف طبقاته فكان لهم دور في دعم الفقراء من خلال رعايتهم العلمية أو الطيبة، أو فلك أسـرى الفقراء، أو تقديم صسدقات مادية لتحسـين أوضـاع المعيثـية لهؤلاء الفقراء، وياتي علي رأس الفئات الداعمـة للفقراء فئة العلمـاء التي أدت دورهـا في المجتمع الأندلســـي من خلال المســاعدات المادية، ومنهم عبد المحسـن بن عبد اله الأنصــاري المعرف بابن الاخرص كان يحبس على الفقراء ويتققد المســـاكين وأهل البيوتات، ويحن عليهم ويكثر لهم العطاء وظل على ذللك حتي وفاته (ابن الفرضــي، 1989م،ج1، ص390) وبالمتل كان فتح بن إبراهيم الأموي "المعرف بابن القتـــاري" فاضـــاً صالحاً، كثير والصدقة (أرسلان، 1936م، ج1، ص121)، كذلك كان عبد العزيز بن أبي عبده حاجب الأمير الحكم الربضـي من أهل الجود والصدقة فعالًا للخير محسـًا إلى الناس كثثر الإسـعاف لهم في الحوائج (ابن حيان: 1994م، ص189-190)، ومتلهـ كان محمد بن فرج الأموي من أهل ريـة متصــــقفًا خيرًا رحيمًا بالفقراء(الخشـني،1989م، ص149)، وهو ما بنطلق على وليد بن عثمان الإثــيلي قيل عنه كان من أهل الصـلاح والفضـل والصـقة (الضـبي،1989م، ج2،صك646)، وكان الوزير هاثـم بن عبد العزيز أبو خالد 
كان رحمة مبسـوطة للعامة والخاصـة فعندما مات لَم يوجد بينًا في قرطبة يخلو من البكاء على هاثـم (ابن الابار، 1989م، ص137-139-139).

هذا بجانب أن وظف المتصــوفة والزهاد الكرامة الصــوفية في إيجاد حلول لكثير من المشـكلات التي عانى منها الفقراء في مجتمع تخللته العديد من التتاقضـات والمفاسـ والانحرافات، علي رأسـها الضـيق المالي والظلم والأمراض كمحاولة منهم للخروج من الواقع المتأزم إلى الواقع المأمون، لذلك اتصـفوا بالصـلاح والورع والعفاف والرحمة بالفقراء والمســـاكين، لاســيَّما أوقات الأزمات ومنهم أحمد بن محمد بن جعفر المخزومي (ت580هـ /1114م)، فقد أنفق أملاكه على الفقراء والمساكين، حتي أنه أنفق عليهم ألفي دينار في غلاءعام 540هـ -1145م (الضبي،1989م،ج1، ص212-213)، كما أنفق ابن قُسي كل ما باعه من أملاك على الفقراء وذي الحاجات (ابن الخطيب، 1973م، ص250) وفي أواخر عصر المرابطين حدث غلاء في بلنسية فقام أبو العباس الأقليثي بتوزيع الطعام علي الضعفاء والمساكين (ابن الآبار، 1989م،ج1، ص56-58 ؛ الضبي، 1989م،ج1، ص213)، وبالمتل كان يحيى بن عبد الرحمن بن عبد المنعم القيسي زاهدًا ورعًا كثير الصدقة والمعروف يعظ الناس (ابن المقري، 1988م،ج3، ص68)، وأيضًا كان المحدث أبو ربيع سليمان بن ابراهيم بن هلال كان رجلًا صالحًا زاهدًا ورعًا فرق جميع ماله وانقطع للجهاد علي الثغور (دبور ،1999م، ص50)، وقد ذكر صـاحب التكملة أن خلصـة الزاهد من أهل قرطبة كان بزارًا ثم ترك التجارة وقسم ماله بين بنية وخصـص اسـهمًا للفقراء من ذللك المال (ابن الآبار، 1985م، ج1، ص194؛ ابن الفرضـي، 1989م، ج1، ص255 ؛ خلاف، 1984م، ص605)، ولمـا زاهد عبد الله بن يحيى الذني يتولى بعض الأعمال الســلطانية في أمواله العظيمة ونبذ الدنيا، فرق كل ذلك علي الفقراء والمســاكين (الضــبي، 1989م، ج2،

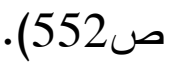

وقد سـى بعض المتصــوفة للبروز بمظر النموذج الأخلاقي في مجتمع تخللته العديد من التناقضـات

والمفاســــــ والانحرافات عن طريق الأداء الكرامي أو الدعاء لهم فقد روي عن الزاهد عبد الله بن المفلس انه مجاب الدعوة وبه تضرب الأمثال في الفضل والعبادة ببلده، وقد عاش أبام بني سلمة في وشقة ولما اظهروا 
فيها الفسـاد والظلم وانتهاك الحرمات بسطوا أيديهم على أموال الناس، فكان أن شكي الناس إلى الزاهد ماهم

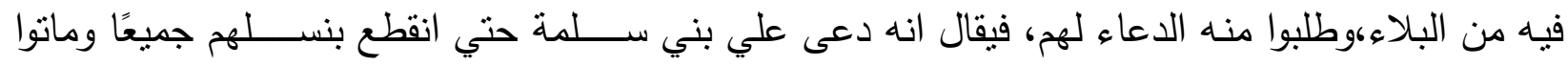
(الخشـــي،1989م، ص216)، ومن صـــور الرعاية الاجتماعية التي قدمها الزهاد والصــــفية إلى الفقراء والمسـاكين، تيسـير عقيقة المولودة لأحد الفقراء، حيث كان من عادة الأندلسـيين سـواء كانو فقراء أم أغنياء ذبح شـاة للصـبي في اليوم السـابع مهما كانت حالته المادية (بوشـتبش، 1993م، ص35)، وكان من فئات المجتمع من يؤثر الفقراء على نفســـه في ســنوات المجاعة وعند اثـــــاد الأزمات ومنهم يحيى بن حجاج الطليطلي، الذي كان يوثر الفقراء على نفسه وعلى أولاده حيث أنه وزع في بعض سنوات المجاعة ماعنده من طعام على المحتاجين والمسـاكين (الخشــي، 1989م،،ص607 ؛ ابن الفرضــ، 1989م،ج2، ص179؛ الحميدي،1989م، ج2،ص596 ؛ عياض، 1983م،ج1، ص459)، وكان بعض أفراد المجتمع يتحرى حق الفقراء في الزكاة فكان الثيخ أبو محمد بن ذنين(ت424هـــ/ 1033م)، فاضًّلا ورعًا صلبًا في الحق كثير الصــــقةـة قيل كان يحصـــي مـاكان ينتجهـ من كرمسه حتى ولو كان عنقودًا واحدًا لتقدير الزكاة (ابن بشكوال،1989م، ج2،ص407)، كما أخذ البعض علي عاتقه دعم المجاهدين في سبيل الهه وتزويدهم بالخيل اللازمة، فضلًا عن تطوع البعض بفلك أسرى الفقراء، ومن أمثالهم عبد الله بن محمد بن عبد الله الخشني كان فاضًّلا رحيمًا بالفقراء يحكى أنه كان يشتري الفرسان للمجاهدين في سبيل الله وذات مرة اشترى فرسًا من رجل فقير كان يبكي فسأله عن حاله فحكى له أنه يبيع فرسـه من أجل فكاك ابنه الأسير ، فأعطاه المال المطلوب

$$
\begin{aligned}
& \text { لفكه ورد إليه فرسه (الضبي،1989م، ج2، ص437). } \\
& \text { - الرعاية الطبية لشرائح الفقراء: }
\end{aligned}
$$

قدم كثير من الأطباء الرعاية الطبية إلى الفقراء والمساكين من عامة الأندلس، فكان الطبيب حمدين بن أبان يقدم الرعاية الطبية إلى عامة الأندلس حيث كانوا يقصـدونه طلبًا للعلاج(ابن جلجل، 1985م،صد3)، وعلى الرغم من انشـــال بعض الأطباء بمهام إدارية في الدولة، إلا أنهم كانوا يهتمون بعلاج عامة الأندلس من الفقراء والمســـاكين إذا قصــدوهم للعلاج، فقد قام الطبيب يحيى بن إســـاق وزير الخليفة عبد الرحمن 
الناصــر بعلاج رجل بدوي جاء شــاكيًا من ألم في أحد أعضـــائه الحســاســـة فعالجه ابن إســـاق(ابن جلجل،1985م،ص 100)، وقد اســتأذن الطبيب أحمد بن يونس الحراني ،الخليفة الحكم المسـتتصــر في صرف العلاج للفقراء والمساكين عندما كان مسئولاً عن الخزانة الطبية في قصر الخليفة، فوافق الخليفة على منح وتقديم العلاج لمرضى الفقراء والمساكين بالمجان، وهو ما يعد مفخرة من مفاخر عصر الخلافة الأموية في الأندلس كما توضـح أيضًنـا دور بعض أفراد المجتمع في التدخل لدى الحكام لمســاعدة الفقراء حيث كان الطبيب أحمد واســـة الفقراء للى الخليفة الحكم(ابن جلجل، 1985م، ص 113؛ الثـــكعة، ص 110؛ البوزبكي، ع 13، 2007م، ص 12)، هذا بجانب الدور العظيم الذي قدمه الطبيب أبو القاسم الزهراوي حيث كان يقضـي نصف يومه منزددًا على دور المرضسى والفقراء والمسـاكين يقدم لهم العلاج بالمجان(الهاثـمي، 2008م، ص 257 ؛ بدر، ص 165)، واهتم أيضَّـــا الطبيب أبو الوليد الكتاني، بعلاج مرضـــى الفقراء والمحتاجين بالمجان(ابن جلجل، ص 109؛ الموساوي32013م، ص 767)، وأمدتتا المصـــادر ببعض الأمتلة على الدعم الذي قدمه بعض أفراد المجتمع إلى الفقراء من خدمات علمية فكان البعض يقرأهم ويعلمه دون أجر إسهامًا منه في تعليمهم مجانًا ومنهم محمد بن سليمان بن أحمد النفزي الذي كان لا يأخذ أجر على القراءة (ابن عسكر،1999م، ص 80)، ولدعم طلاب العلم غير القادرين عمد بعض أفراد المجتمع إلى تقديم الطعام وسـبل الراحة لهؤلاء الطلاب فكان الفقيه أحمد بن سـعد بن كوثر الأنصـاري يقدم الطعام لطلبة العلم الفقراء(ابن بثـكوال، 1989م،ج1، ص 72 - 73)، وكما تكفل البعض بطلبة العلم،وكنموذج ذلك تكفل أسرة بني ذكوان،بأبي عبد الله بن الحناط الذي كاد أن يترك طلب العلم بسبب فقره (والي،1996م، ص 133).

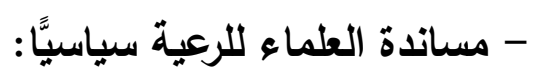

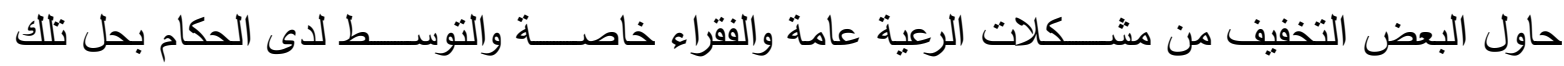
المشكلات، ومنهم الثـاعر أبو إسحاق الإلبيري فعندما عانى الناس من نفوذ الوزير اليهودي ابن النغزله الذي سبطر على الثُئون المالية، وأرهق الرعية بالضرائب أيام الأمبر باديس بن حبوس، ذهب الإلبيري إلى باديس 
وطلب منـه أن يحد من نفوذ وزيره(عبـاس، 1997م، ص 109- 110؛ عبد الرحي،،2009م، ص99111)، ويهتم بأمر الرعية الذين أصابهم الفقر بسبب كثرة الضرائب والمغارم المفروضة عليهم، كما برز دور الفقهاء جليًا في تحريض العامة بقرطبة على الثورة ضد الأوضـاع المتردية والسياسات الظالمة والقاسية التي اتبعها الحكم بن هشـام حتي قامت ثوراتهم ضده فيما عرف بهيج الربض الأول (202هـ/808ه)، ولاريب فقد

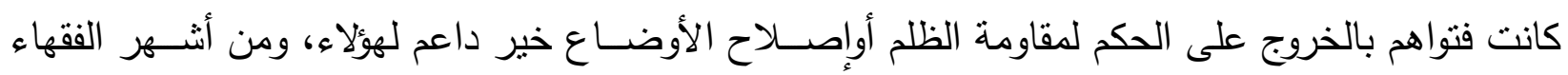
والمفتيين في هذا الصـدد: يحيى بن يحيى الليثي وعيسـى بن دينار من أثــهر المفتين الذين وقفوا أمام ظلم الأمير الحكم وطالبوا بحق الرعية بدون خوف أو جبن(ابن الأثير،1987م،ج4، ص 74؛ ابن ســـيد، دت،جر1، ص 43 ؛ مؤنس، ص 23). كما أخذ مجموعة من الفقهاء ورجال الفكر على عاتقهم مهمة دعوة ملوك الطوائف إلى التكاتف والوحدة من أجل الوقوف أمام زحف وخطر النصارى المستمر الذي أنى على كل شيء بالخراب والفقر ومن الذين تزعموا هذه الدعوات سليمان بن خلف الباجي، وبعض العلماء الأخرين(الضبي،1989م ، ص 383- 384).

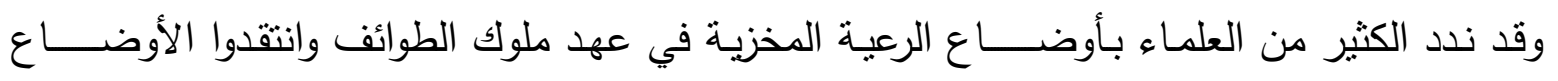
الإجتماعية والإقتصــادية ومنهم ابن حزم حيث ندد بالفتنة وتأثيرها على الأوضـــاع في الأندلس فقد انتثـر الفسـاد بين عمال المدن وولاتها، ينهبون أموال الرعية عن طريق فرض المغارم والضــرائب الباهظه فانتشـرت السـرقة والنهب حيث ســلطوا اليهود علي رقاب المســمين فعانى الناس كثثراً(ابن حزم ، 1987م،ج3، ص 173- 177؛ المنوني، 1991م، ص 125- 128)، وفي هذه الرسـالة كان ابن حزم ينكر الأوضـاع، كما أنه يحث الفقهاء على إنكار الأمر، والأمر بالمعروف والنهي عن المنكر، وكان للعلماء دور كبير في الوقوف أيضًا بجانب الرعية في نهاية عصر المرابطين عندما ساءت الأحوال وانتشرالظلم، وارتفعت الأسعار ونقصت الأقوات حتى عز على الفقير شـرائه هذا بجانب عودة النصـارى لغزو المسـلمين فتحطمت آمال المسـلمين، لذلك انقلب حبهم إلى كره ومقت للمرابطين، فنار أهل قرطبة، وانضــم العلماء إلى الثـعب وأفنتا بأن الخروج علي المرابطين جائز (خليفة، ص 239). 
فقد حرص أهل الثراء من أفراد المجتمع الأندلسي علي الحبس على الفقراء والمساكين وقد شمل الوقف، وقف العقارات والأراضـي والحوانيت لخدمة الفقراء والمسـاكين ومسـاعدتهم في إقامة معيثـتهم وإغانثهم في بعض الأحيان عن ذل السؤال؛ فقد نوافرت كثير من التفاصسيل في كتب الفتاوى والنوازل عمن حبس ضيعة على فقراء أهلـه لتوفير القوت والكســـوة لهم وتوزيع مـا يتبقى علي الفقراء من غير القرابـة(ابن ســـــل، 1995م،ج1، ص 562 ؛ الونشـــريســــ1981م،ج7،صـ477- 478)، وعمن حبس ثمـار علي فقراء المسـاكين بقرطبة، حتي عرفت تللك الأرض باسـ أرض المسـاكين(الونشـريسي، 1981م،ج7، ص 63؛ أبو مصـطفى، 1997م،ص 203)، وتوجد نازلة ســئل فيها المواق عن رجل أوصـى بفدان يكون حبـَـا على المساكين بعد وفاته يؤخذ فائده كل عام ويشتري به خبز ، ويفرق على الضـفاء والمساكين في شهر رمضـان وأوصى أيضًا بأن ما يفضل عن الفدان يلحق بالصدقة(الونشريسي، 1981م،ج7، ص 182- 183)، ومن ضــمن الرعاية الإجتماعية التى توفرت للفقراء والمسـاكين عن طريق الأحباس توفير المسـكن والمأوى لمن لامأوى له فقد أوقف الكثير من أفراد المجتمع الأندلسـي المنازل ليســـنها الفقراء والمســاكين ومنها الدور المنسوبة إلى نيروز فضلًا عن الزوايا المخصصة لسكن الفقراء(الونشريسي ، 1981م،ج7، ص 220). وقد سـاعدت الأحباس الفلاحين الفقراء كثيرًا وذلك من خلال توفير البذور للذين لا يستطيعون شـراءها للزرع، فتزد نازلة تتعلق برجل أوصـى عند موته أن يخرج من ثلث متخلفه مائة قدح شــعير توقف حبسًـــا ليستلفها الفلاحين الفقراء غير القادرين على شراء زرع يزرعونه، فإذا فض الزرع أعاد ما استلفه مكانه وهكذا (الونشـريسـي، ج7، 1981م،ص 120؛ حجي 1999م، ص 105)، هذا بجانب الوقف النقدي على الفقراء والمســاكين فقد ســئل عبد الله العبدوس عن دراهم موقوفة على المســاكين وأخرى عن الحجاج وأخرى عن المسجونين(الونشـريسي، 1981م،ج7، ص 44- 45) وقد سـاعد الوقف في العملية التعليمية كثيرًا فقد وجد الكثير من الحبس على طلاب العلم، فقد حبس كثثر من الفقهاء والعلماء كتبه على طلبة العلم، من هؤلاء هارون بن سـالم من أهل قرطبة (ت238هـــ/852م) وأيضـاً قاسم بن سـعدان بن عبد الوارث من أهل رية 
(ت347هـ /958م)، وفي الاطار ذاته شرط البعض في عقد الحبس على أبنائه غن انقرضوا أن يرجع مردود الحبس علي طلبة العلم(خلاف،1984م، ص 60).

وانطلاقًا من تضامن المجتمع مع الفقراء والمساكين فقد شمل الحبس جميع سبل المعيشة وهو ما تؤكده نازلة عن رجل جعل لبن بقرته للمساكين(الونشريسي، 1981م، ج7، ص 105)، كما حبس البعض الطواحين على الفقراء والمساكين ومنها الثلاث طواحين الموجودة بحص الرحى قرب قرطبة(الونشريسي، 1981م،ج7، ص461 ؛ ابن رشد القرطبي،1987م،ج2، ص 1051)، وكان من عادات أثرياء الأندلس التصدق والحبس على الفقراء في الإحتفالات الدينية ومثال ذلك حبس امرأة غرناطية موضـع على ليلة المولد النبوي الثـريف، بحيث يزرع ذلك الموضـع، ويؤخذ قحه ويوزع على الفقراء في هذه الليلة عندما يجتمعون للذكر (الونشريسي،

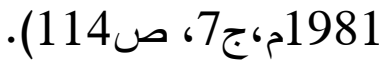

كما اهتم أهل الأندلس بالفقراء أحياءً وأموانًا وذلك من خلال ما حبسـهـ الأندلسـيون على المقابر ، فقد حبسـوا الأراضـي على المقابر لبنائها، كما حبس رجل من كورة قرطبة أرضًا لدفن موتى المسلمين(ابن رشدـ: فتاوى،

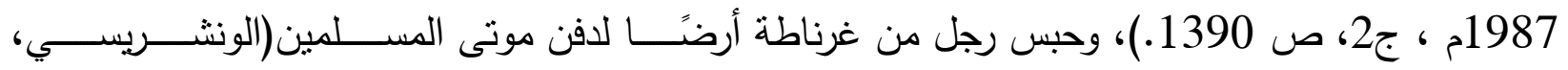

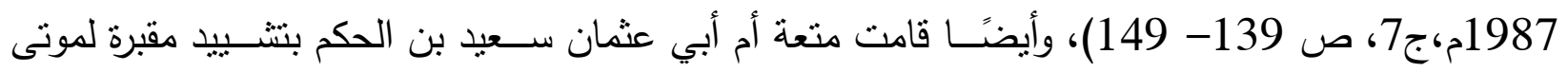
المسلمين فكان من الطبيعي أن يدفن فيها الفقراء والمساكين الذين ليس لديهم مقابر (ابن حيان،2003م، ج2،

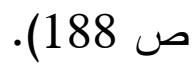

نال مرضـى الفقراء والمســاكين نصـيًاً من تلاك الأحباس فكان يصـرف من هذا الحبس على رواتب الأطباء وغيره، ومنها منية عجب جارية الحكم الربضي وكانت تشـمل على بعض مسـاكن موقوفة على المرضىى(ابن حيان،2003م، ج2، ص 188؛ ســـالم، ص 209)، وبالمثل كانت الثـــاء حظية الأمير عبد الرحمن بن الحكم (206- 232هـ)، لها الكثثر من الأوقاف على المساجد والمرضى والضعفاء(ابن حيان، 2003م،ج2، ص 304 ؛ حوالة، 2002م، ص 174)، ونظرًا لأهمية الأحباس في المجتمع نالت اهتمام المؤســســــة القضـائية، وبرزت تثـريعات القضــاة من أجل الحفاظ علي تلك الاحباس وصـيانتها وضـمان مردودها، ومن 
ذلك عدم عقد قبالة لهذة الأرض المحبسـة لأكثر من أربعة أعوام، خوفًا من نهبها إن ظلت فترة طويلة بأيدي منقبليها ومن هؤلاء القاضي ابن السليم (ت376هـ/977م)( ابن رشد، 1987م،ص235-237)، ومن خلال العرض السـابق يتضــح أن الأحباس كان لها دور في التخفيف من أثار الفقر والبؤس والمرض، فضــلاً عن توفير الرعاية الصحية والتعليمية للفقراء(أبو مصطفى، 1997م،ص 203).

\section{الخاتمة}

من خلال ما سـبق ذِكره يمكن القول: إنَّ هذه الدراسـة عبارة عن رؤية تاريخية للتعرُّف من خلالها على إبراز دور الدولة والمجتمع في مواجهة الفقر، حيث سـعينا إلى عرض دور وجهود الحكام تجاه الفئات الفقيرة والمحتاجة، وذلك بالنظر في أمورهم والســعي لحلها والتخفيف منها، حيث برز دور حكام الدولة الأمويـة وبعض حكام المرابطين في مساعدة الفقراء بشكل كبير ولكن غاب دور ملوك الطوائف في دعم الفقراء؛ وذلك بسبب انثـغالهم بصـراعتهم الداخلية من جهة، بجانب أنهم نزعوا إلى حباة الترف والرفاهية لإرضـاء نزواتهم وشهواتهم فأتقلوا كاهل الرعية بالضرائب من أجل مصلحتهم الثخصية، ومهادنتهم للنصارى لذلك شكلو عبئًا على الفقراء ولم يدعموهم، وكان لمؤسسة القضاء دورٌ عظيمٌ في تقديم الدعم المادي والمعنوية للفقراء فحقّت. العدل بين الفقراء والأغنياء بجانب تصـــدّق الكثير من القضـــــاة بأموالهم على الفقراء خاصـــــة أيام المِحَن والكوارث، والتوسط لدى الحكام لقضاء حوائجهم فكانت مؤسسة بنتشر بين أرجائها العدل. وكان لمؤسـســة الحسـبة دورٌ في دعم الفقراء وأخيرًا دور المجتمع خلال التقرب منهم ومشـــاركتهم محنهم

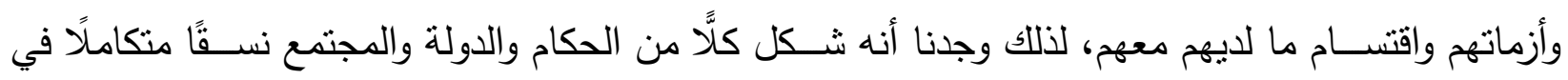
السعي لمساعدة الفقراء وتحسين مستواهم.

قائمة المصادر والمراجع

ابن أبي زرع، علي الفاسـي، (1972م)، الأنبس المطرب، الطبعة الأولي، الرباط، دار المنصـــور للطباعة. 
ابن الآبار : عبد الله محمد بن عبد الله بن أبي بكر القضاعي، (1989م) التكملة لكتاب الصلة، الطبعة الأولى، القاهرة، دار الكتاب المصري. - - (1985م)، الحلة السبراء، الطبعة الثانية، القاهرة، دار المعارف.

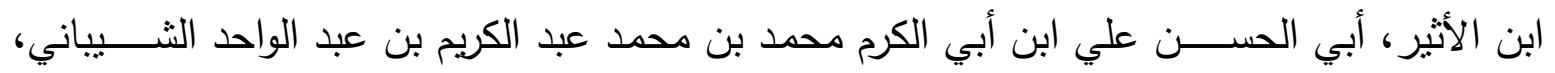
(1987م)، الكامل في التاريخ، الطبعة الأولي، بيروت، لبنان، دار الكتب العلمية. ابن الخطيب: أبى عبد الله محمد بن عبد الله بن سـعيد الغرناطي الأندلســي، (1974م)، الإحاطة، الطبعة الثانية، مكتبة الخانجي، القاهرة. ابن الخطيب: أبي عبد الله محمد بن عبد الله بن سـعيد الغرناطي الأندلسي،(د-ت)، أعمال الأعلام، الطبعة الثنانية، بيروت، لبنان، دار الكتب العلمية. ابن الفرضي، عبد الله بن محمد بن يوسف بن نصر الأزدي، (1989م)، تاريخ علماء الأندلس، الطبعة الثانية، القاهرة، دار الكتاب المصري • ابن القطان، أبو محمد حســن بن علي بن محمد بن عبد الملك الكتامي، (1990م)، نظم الجمان لترتيب ما سلف من أخبار الزمان، الطبعة الثانية، دار الغرب الإسلامي. ابن الكردبوس: عبد الملك بن أبي القاســـ (1995م)، الاكتفاء في أخبار الخلفاء، مكتبة الملك فهد الوطنية، الجامعة الإسلامية. ابن بسام، أبي الحسن علي ابن بسام الثنتريني(1975م)، الذخبرة في محاسن أهل الجزيبة، بيروت، لبنان، دار الثقافة. ابن بسـام، محمد أحمد بن بسـام المحتسـب (2003م): نهاية الرتبة في طلب الحسـبة، تحقيق: محمد حسن محمد حسن اسماعيل وأحمد فريد المذيري، ط1، دار الكتب العلمية، بيروت - لبنان. ابن بشكوال، أبو القاسم خلف بن عبد الملك بن مسعود بن موسى، (1989م)، الصلة، الطبعة الأولى،

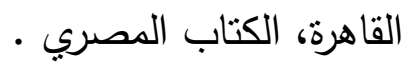


ابن جلجل، أبي داود ســليمان بن حســان الأندلسـي، (1985م)، طبقات الأطباء والحكماء، الطبعة الثانية، بيروت- لبنان، مؤسسة الرسالة. ابن حزم: علي بن أحمد بن سعيد، 1968، فضـائل الأندلس، تحقيق صـلاح الدين المنجد، دار الكتب

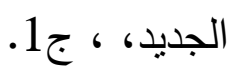

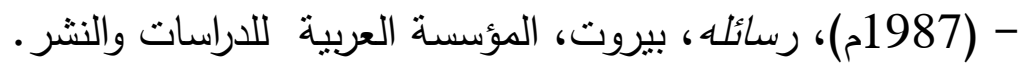
ابن حيان: أبي مروان بن حيان القرطبي، (1965م)، المقتبس فى أخبار بلد الأندلس، بيروت، لبنان، دار الثقافة. - - (1979م)، المقتبس ، ج5 ، الرباط ، العربى للنقافة. - - (1994م)، الدقتبس من أنباء الأندلس، القاهرة. ابن رشد، أبي الوليد محمد بن احمد بن رشد (1987م): فتاوى /بن ششد، الطبعة الأولى، بيروت، لبنان

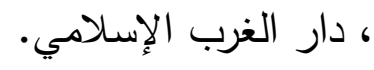
ابن ســيد المغربي، أبو الحسـن علي بن موسـى، (2004م): الدقتطف من أزاهر الطرف، القاهرة، الهيئة العامة لقصور الثقافة. ابن سـهل، أبي الأصـبخ عيسـى ابن ســل ابن عبد الله الأزدي، (1995م)، الأعلام بنوازل الأحكام، الطبعة الأولي. ابن عبدون: محمد بن أحمد بن عبدون التجيبي(1955م)، سالة في القضاء والحسبة، القاهرة، مطبعة المعهد العلمي الفرنسي للآثار الثرقية. ابن عذاري، أبو العباس أحمد بن محمد، 1983، البيان الدغرب في أخبار الأندلس والدغرب، الطبعة الثالثة، بيروت، دار النقافة. ابن عسكر وابن خميس، (1999م): أعلام مالقة ، الطبعة الأولى، بيروت، دار صادر . أبو الفداء : عماد الدين إسماعيل بن محمد بن عمر، (د-ت)، تقويم البلدان، بيروت دار صادر . 
أحمد هيكل، ( 1985م): الأدب الأندلسي من الفتح حتى سقوط الخلافة، القاهرة، دار المعارف. الأخضر ، خيرية عمران (2018)): " المؤسسات التعليمية في الأندلس خلال القرنين الرابع والخامس

الهجريين"؛ ع16، مجلة العلوم الإنسانية، جامعة المرقب، ليبيا. •أرسلان، شكيب،(1936م): الحلل السندسية في الأخبار والآثار الأندلسية، بيروت، لبنان. الأوسي، حكمت علي،(د-ت): فصول في الأدب الأندلسي، بغداد، مطبعة سليمان الأعظمي. بدر ، أحمد، (د-ت): الحباة الفكرية في الأندلس، الطبعة، المدينة، دار النشر . بدر ، مصـفى (2009م): موسـوعة التاريخ الإسـلامي من قبل ظهور الإسـلام وحتى سقوط الخلافة العثمانية، ج2، الطبعة الأولى، القاهرة، مركز الراية للنشر. البوزبكي، توفيق ســطان (2007م):الحضـارة العربية في الأندلس وأثرها في أوربا، مجلة كلية الآداب

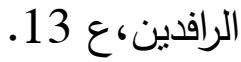
بوشـتيش، إبراهيم القادري، (1993)، المغرب والأندلس في عه المرابطين، الطبعة الأولى، بيروت-

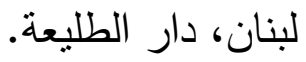
البيلي، محمد بركات (1993م): الزهاد والمتصـــفـة في بلاد الدغرب والأندلس حتى القن الخامس الهجري، القاهرة، دار النهضة العربية. التواني، عبد الكريم، (1967م): مأسـاة انهيار الوجود العببي في الأندلس، ط1، مكتبة الرشـاد، الدار البيضاء. جمعة، أحمد خليل، (2001م): نسـاء من الأندلس، الطبعة الأولى، دمثـق، بيروت، اليمامة للطباعة والنشر. حتاملة، محمد عبده، (1999م) ، موسوعة الديار الأندلسية، الطبعة الأولى، عمان، الأردن. حجي، محمد، (1999م): نظرات في النوازل الفقهية، الطبعـة الاولى، المغرب ، الجمعيـة المغربيـة للتأليف والترجمة 
حسن خليفة وحسن مراد وآخرون، (1938م): تاريخ العرب في أفريقية والأندلس، رقم الطبعة، القاهرة، مطبعة الاعتماد.

حسن، قرني حسن، (2012م): الهجتمع الريفي في الأندلس عصر بنى أمبة، الطبعة الأولى، القاهرة،

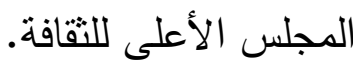
حسن، محمد بشـر، (د-ت): فصـول في إيداعات الطب والصـيلة في الأندلس، رقم الطبعة، بيروت،

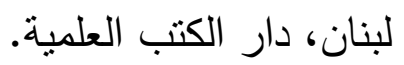

هسنين، إبراهيم محمد، (2013م) ، تاريخ الإسلام في الأندلس ، دار التعليم الجامعي، ليبيا. حمادة، محمد ماهر (1986م): الوثائق السياسية والإدارية في الأندلس وشعال إفريقية، الطبعة الثانية، مؤسسة الرسالة. الحموي: شهاب الدين أبي عبد الله باقوت، (1977م) ، معجم البلدان، بيروت، دار صادر . الحميدي: أبو عبد اله محمد بن أبي نصـر فتوح، (1989م) ، جذوة الدقتبس في تاريخ علماء الأندلس ، الطبعة الثانية، القاهرة، دار الكتاب المصرى. الحميري: عبد الله محمد بن عبد الله بن عبد المنعم (1988م)، الروض الدعطار، الطبعـة الثانية،

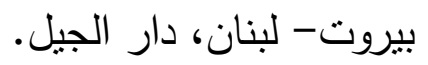
اللبودي، حنان مبروك (2014م): التنجيم والمنجمون، مجلة كلية التربية ،جامعة الاســـكندرية، ع1، .24 حوالة، يوسف بن أحمد (2002م): المرأة في البلاط الأموي في الأندلس (138هـــ- 755م/ 4221030م)، حوليات الأداب والعلوم الاجتماعية، حولية 24. الخشني: أبو عبد الله محدد بن الحارث بن أسد، 1989م، قضاة قرطبة، القاهرة، دار الكتاب الدصرى. - (1991م): أخبار الفقهاء والدحدثين، مدريد، المجلس الأعلي للابحاث العلمية (معهد التعاون مع

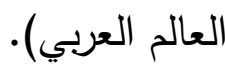


خلاف، محمد عبد الوهاب (1992م): تاريخ القضـاء في الأندلس، الطبعة الأولي، المؤسـسـة العربية

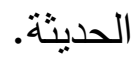
خلاف، محمد عبد الوهاب، (1984م): قرطبة الإسلادية في القرن الحادي عشر الميلادي- الخامس الهجري (الحباة الاقتصادية والاجتماعية)، الدار التونسية للنشر . دبور ، محمد علي السـعيد (1999م): الدور السـياسـي والاجتماعي في الأندلس في عهدي الدرابطبن والدوحدين، رسالة ماجستير غير منشورة، كلية دار العلوم، جامعة القاهرة، مصر . دندش، عصـمت عبد اللطيف : الأندلس في نهاية المرابطين ومستـكل الدوحدين، بيروت- لبنان، دار الغرب الإسلامي. دويدار، حسـن يوسـف (1994م)، المجتمع الأندلسـي في العصـر الأموي، القاهرة، مطبعة الحسـن

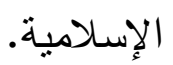
الذهبي: شمس الدين محمد بن أحمد بن عثمان، (1996م)، سير أعلام النباءء، الطبعة الحادية عشر،

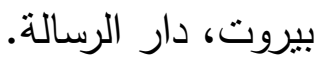
ريبيرا ، خوليان، (1994م): التربية الإسـامبية في الأندلس وأصسولها المشرقية، ترجمة: الطاهري أحمد مكي، الطبعة الثانية، دار المعارف. الزناتي، أنور محمود (ديسمبر 2012م): الثقافة الشعبية في الأندلس، جامعة عين شمس، كلية التربية،

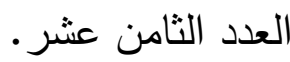
زيادة، نادر فرج، (2010م): الترف في المجتمع الأندلسي(92هـ/711م-668 هـ/1269م)، رسالة ماجستر غير منشورة، الجامعة الاسلامية، غزة. زينل، نهاد عباس (2013م): الإنجازات العلمية للأطباء في الأندلس " وأثرها على التطور الحضـاري

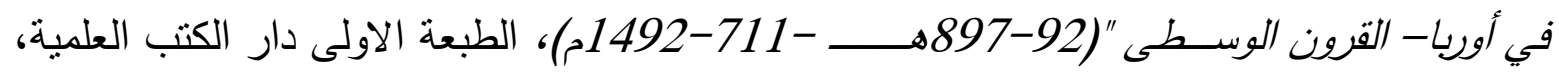


سـالم ، السـيد عبد العزيز، (1997م): قرطبة حاضــة الخلافة، الإسـكندرية، مصـر ، مؤســـة شـباب الجامعة.

سيديو، لويس، (د - ت)، خلاصة تاريخ العرب، ترجمة: محمد أحمد عبد الرازق، مؤسسة هنداوي. الثـعكة، مصطفى (1987م): الدغرب والأندلس ( آفاق إسـالاعية وحضـارة إبـالعبة)، الطبعة الأولى، القاهرة، دار الكتاب المصرية. صالح، وائل فؤاد، (1992م): جهود الحكم المستتصر في تطوير الحركة العلمية، مجلة النجاح للعلوم

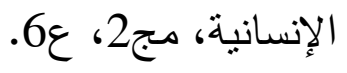
الضـبي: أحمد بن يحيى بن أحمد بن عميرة الضـبي، (1989م)، بغية الدلتصس في تاريخ رجال أهل الأندلس، القاهرة، الطبعة الأولى، دار الكتاب المصري. ضيف، شوقي، (1989م)، عصر الدول والإمارات، القاهرة، دار المعارف. عباس، إحسان، (1997م): تاريخ الأدب الأندلسي، الطبعة الأولى، عمان، دار الثروق. عبد الرحيم، محمد عبد السـميع، (2009م): شـعر الفتن في الأندلس في القرنين الخامس والســادس الهجريبين، رسالة ماجستير غير منشورة، جامعة القاهرة، مصر. عبد الرؤوف، أحمد بن عبد الله، (1955م): في آداب الحســبة والمحتســب ، القاهرة، المعهد العلمي الفرنسي.

التركي، عبد الله عبد المحسن، (1994م): الأندلس الدرس والتاريخ، مصر ، دار المعارف الجامعية. عرفة، محمود (يوليو 1993م)، خطة الثرطة في الأندلس في عهد الخليفة المستتصر (350- 366 هـ) (961- 979م)، مجلة قسم التاريخ، ع11. العروس، مصـطفى، (1997م): الددرسـة المالكية الأندلسـبة إلى نهاية القرن الثالث الهجري، الطبعة الأولى ، المملكة المغربية، وزارة الاوقاف والثئون الإسلامية. على، محمد كرد، (1923م)، غابر الأندلس وحاضرها، ط1، مصر ، المكتب الأهلية. 
عمر فروخ، (1984م) : تارخ الأدب العربي ، الطبعة الثانية، بيروت،لبنان، دار العلم للملايين. عمر، يحيى، (1956م): أحكام السوق، المجلد الرابع، مطبعة المعهد المصري، مدريد. عنان، محمد عبد الله ، (1997م): دولة الإســلام في الأنلس، القسـم الأول، الطبعة الرابعة، القاهرة، مطبعة الخانجي. عويس، عبد الحليم (1994م): الثكاثر المادي وأثره في سقوط الأندلس، القاهرة ، دار الصحوة. عياض، أبو الفضـل بن موسـي، (1983م)، ترتيب الددارك وتقريب المســالك لـعرفة أعلام مذهب مالك، الطبعة الثانية، المغرب، وزارة الاوقاف والثئون الاسلامية. فاضـل فتحي والي، (1996م): الفتن والنكبات الخاصـــة في الثــعر الأندلســى، الطبعة الأولى، السعودية، دار الأندلس للنشر والتوزيع.

• فرغلي، إبراهيم، (2006)، تاريخ وحضارة الأندلس، الطبعة الأولى، القاهرة، العربي للنشر والتوزيع. الفهري، علي محمد شـايع، (2016م)، الحباة السـباسـبة ومظاهر الحضـارة في مدينة مالقة ، الطبعة

الأولى، القاهرة، مكتبة الثقافة الدينية. القرشي، محمد بن محمد بن أحمد، (1976م)، معالم القرية في أحكام الحسبة، الطبعة الاولى، القاهرة، الهيئة المصرية العامة للكتاب. الكحلوت، يوسف شحدة، (2010م): الأخلاق الإسلامية في الثعر الأندلسي"عصر ملوك الطوائف"،

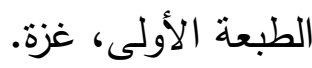
كمال أبو مصطفى، (1997م) : بحوث في تاريخ وحضارة الأندلس، الطبعة الأولى، مركز الاسكندرية للكتاب. اللخمي: أبي الحسن علي بن محمد اللخمي(1432هـ - 2011م )، التبصرة، تحقيق: أحمد عبد الكريم نجيب، الطبعة الاولى، قطر ، وزارة الاوقاف والثئون الإسلامية. 
لطوف، فوزي عزاوي، (2018م)، النظـام الهـالي والنقدي بـالأنـلس في عهـ الامــاث(138316هـ/755-9299)، الطبعة الأولي، مؤسسة الوراق للنشر والتوزيع. لوثينا، لويس سيكو دي، (1992م): الحموديون سادة مالقة والجزبية الخضراء، ترجمة عدنان محمد آل طعمة، دمشق، مطبعة الثام. لين بول، ستانلي، (1944م): قصة العرب في أسبانيا، ترجمة: علي الجارم، دار المعارف. مجهول، مؤلف (1983م): ذكر بلاد الأندلس، ددريد، المجلس الأعلي للأبحاث العلمية. مجهول، مؤلف (1989م): أخبار مجدوعـة، تحقيق: إبراهيم الابيـاري، الطبعـة الثانيـة، القاهرة، دار الكتاب المصري. مجهول، مؤلف(2007م): تاريخ الأندلس، الطبعة الاولى، بيروت، لبنان، دار الكتب العلمية. محمد علي عباد حميسان، (د-ت)، صور من مفاخر القضاء في الإسلام. المراكثي، (2006م): أبي محمد بن عبد الواحد بن علي، المعبب في تلخيص أخبار المغرب، الطبعة الأولى، صبدا، لبنان، المكتبة العصرية. المعموري، محمد عبد الله، (2012م) ، " الحســبـة في الأندلس "، جامعة بابل - كلية التربية للعلوم الإنسانية، ع 10 المعائ، 10.

المقري (1940م): أزهار الرياض في أخبار عياض، ج2، القاهرة، مطبعة لجنة التأليف والترجمة.

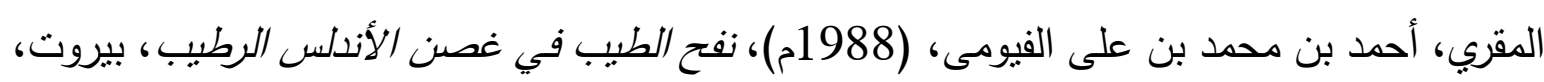
دار صادر .

مكي، محمود علي (2016م): وثائق تاريخية جديدة عن عصــر المرابطين، المجلد 7- 8، دار المنظومة. المنوني وآخرون، محمد (1991م): التاريخ الأندلســي من خلال النصـــوص، الطبعة الأولى، الدار البيضاء. 
مورنيو، مانويل جوميث، (د.ت) : الفن الإسـاعـي في أسـبانيا ، نرجمة: السـيد عبد العزيز سـالم: لطفي عبد البديع، مؤسسة شباب الجامعة، الإسكندرية.

الموسـاوي،عطارد تقي عبود(2013م)، تطور الطب في الأنلاس منذ عهد خلافة بني أمية وفي نهاية

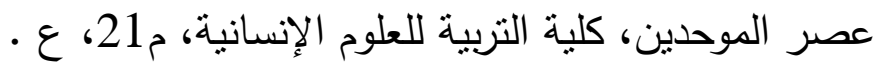
مؤلف مجهول (1979م): الحلل الموشية في ذكر الاخبار المراكشية، الطبعة الأولى، دار الرشاد. مؤنس، حسين، (1997م)، شيوخ العصر في الأندلس، القاهرة، دار الرشاد. النباهي: أبو الحسـن بن عبد الله بن الحسـن، (1983م)، تاريخ قضــاة الأندلس، الطبعة الخامســة، بيروت، دار الآفاق الجديدة. الهاتشمي، عبد المنعم، (1429هـ- 2008م)، موسوعة العلداء والعباقرة المسلمين، دار ومكتبة الهلال،

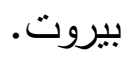
الهرفى، سـلامة ســمان، (1985م)، دولة المرابطين في عهـ علي بن بوسـف بن تاثـقين ( دراســة سياسية وحضارية)، دار الندوة الجديدة . •الونشريسي، أبي العباس أحمد بن يحيب، (1981م)، المعيار، الرباط، دار الغرب الإسلامي. 
The state and society's role in the face of poverty in Al-Andalus during the Umayyad era till the end of Almoravid era. (138 AH-756 AD -539 AH- 1085AD)

Prepared by student

Abeer eid mohamed

Teaching Assistant, History Department

Faculty of women for Arts, Science and Education

Ain Shams University

supervised by:

Prof.Dr. Ahmed Ibrahim El Shaarawy,

Prof. of history and Islamic civilization.

Faculty of women, Ain shams university.

Prof. Dr. Afifi Mahmoud Ibrahim, Prof of history and Islamic civilization.

Faculty of Arts, Benha university.

\begin{abstract}
:
The study aimed to know the role of the state and society in facing poverty, this is by highlighting the effect of poverty on the prevalence of the culture of solidarity and synergy among the rulers and the different categories of society towards those disadvantaged and marginalized categories in society, by recognizing efforts made to improve their status by providing financial and moral support and the fulfillment of their needs by rulers, state institutions and different categories of society.
\end{abstract}

Keywords: Andalus-poor-people-rulers-society-care-judiciary-counting 